\section{Keywords:}

- Spitsbergen

- svalbard

- Cenozoic

- Paleocene

- Transgressive

- Coal

- Coastal

- Pain

- Mires

Received:

15. October 2019

Accepted:

5. April 2020

Published online:

27. July 2020

\title{
Sedimentary facies and reconstruction of a transgressive coastal plain with coal formation, Paleocene, Spitsbergen, Arctic Norway
}

\author{
Charlotta Jenny Lüthje ${ }^{1,2}$, Gary Nichols ${ }^{1,3}$ \& Rhodri Jerrett ${ }^{4,5}$ \\ ${ }^{1}$ University Centre on Svalbard, P.O. Box 156, Longyearbyen, N-9171, Norway \\ 2Present address: GeoScandia, Sandbjergvej 34-36, 2950 Vedbæk, Denmark \\ ${ }^{3}$ Present address: RPS, Goldvale House, 27-41 Church Street West, Woking, Surrey, GU21 6DH, U.K. \\ ${ }^{4}$ School of Environmental Sciences, University of Liverpool, Liverpool, L69 3GP, U.K. \\ ${ }^{5}$ Present address: Department of Earth and Environmental Sciences, The University of Manchester, Oxford \\ Rd, Manchester, M13 9PL U.K. \\ E-mail corresponding author (Charlotta Lüthje): cl@geoscandia.com
}

Analysis of coal-bearing strata in the Paleocene Firkanten Formation in the Central Tertiary Basin of Spitsbergen (Svalbard) has shown that deposition was in a coastal plain setting. Interpretation of numerous cores indicates that deposition occurred in coastal plain mires, lagoons, tidal inlets, barrier bars and shoreface environments. These form a series of shallowing-up successions metres to tens of metres thick. Correlation between boreholes over distances in excess of $100 \mathrm{~km}$ proved challenging with no regional marker horizons. However, by constructing paleogeographic maps as part of the process of correlating, and by using analogous modern coastal areas as indicators of facies belt widths, a correlation scheme that provides patterns of facies distribution that are consistent in three dimensions has been created. The resulting stratigraphic framework comprises parasequences grouped into parasequence sets that show an overall retrogradational pattern representing a stepwise transgression over a basin floor that was subsiding due to flexural subsidence. Absence of incision or other evidence for relative sea-level fall within the whole succession suggests that flexural subsidence was sufficient to keep pace with eustatic sea-level falls. The basal unconformity surface is overlain by a poorly sorted deposit of reworked regolith that forms a strongly diachronous unit, occurring at the base of successive parasequences. Individual parasequences formed in response to relative sea-level rises that are considered likely to be eustatic in origin and resulted in flooding of the coastal plain. Centimetre-scale analysis of the coal maceral distribution through the thickness of the lowermost major coal seam indicates that there were also higher-frequency fluctuations of relative sea level, possibly at Milankovitch-scale, during the deposition of individual parasequences. This new facies model and interpretation of the subsidence history of the basin provides a framework for understanding the distribution of sediments within a coal-bearing coastal plain succession.

(c) Copyright the authors.

This work is licensed under a Creative Commons Attribution 4.0 International License.
Lüthje, C. J., Nichols G. \& Jerrett R. 2020: Sedimentary facies and reconstruction of a transgressive coastal plain with coal formation, Paleocene, Spitsbergen, Arctic Norway. Norwegian Journal of Geology 100, 202010. https://dx.doi.org/10.17850/njg100-2-1. 


\section{Introduction}

Peat-forming mires can occur in a variety of depositional settings, from fluvial overbank settings with no direct connection to the marine realm to delta-plain environments and coastal plains (e.g., Fielding, 1985; Moore \& Shearer, 2003). In the stratigraphic record, recognition of the character of the facies associated with coal seams provides a means for determining the environment of deposition and, since the spatial distribution of the peat deposits is a function of the depositional setting, the lateral distribution of coal seams. The occurrence of coal seams within a succession is controlled by the way the depositional environment has evolved through time, which is a function of sediment supply and relative changes in accommodation due to subsidence and sea-level variations (Cross, 1988; Petersen et al., 1988). Facies analysis and stratigraphic analysis using the sequence-stratigraphic approach therefore provide the means for documenting and predicting the distribution of coal seams in outcrop and in the subsurface.

In this case study from a succession of Paleocene coal-bearing strata from the island of Spitsbergen in the Norwegian Arctic Svalbard archipelago, detailed thorough facies analysis has been used to establish the environment of deposition of peat-forming mires and document reasons for preferring a coastal plain setting over the previous models that suggested formation in a deltaic setting (Steel et al., 1981, 1985; Harland, 1997; Dallmann, 1999; Bruhn \& Steel, 2003). There are some limitations to the depositional model of previous interpreters; the models were not based on systematic facies analysis identifying the different facies in detail, the data used were limited and mostly field data, models were biased on the interpretation of the coal environment, the facies description missed differentiation of conglomerates, the analyses were not made in a sequence-stratigraphic context or paleogeographic reconstruction. These are key elements in the understanding that has come out as crucial for the interpretation of the development of the Firkanten Formation ( $\mathrm{Fm})$.

The coastal plain model has then been used to guide correlation between boreholes over an area approximately 100 by $40 \mathrm{~km}$. The coal seams could not be assumed to be regional marker beds because the mires developed in different positions through time in response to changing relative sea level and sediment supply. No other depositional units could be considered to form valid marker horizons, so correlation between the 21 borehole successions used in this study was carried out using an iterative process of developing models for the paleogeographic development of the area when correlating 2D cross-sections. The resulting model for the evolution of the area comprises a series of stacked shallowing-up packages that overall form a retrogradational pattern indicating deposition in a long-term transgressive setting.

The exceptional quality of the core material and the spacing of the boreholes mean that the data from this area provide a well-documented case study for coal formation in a transgressive coastal plain environment. In this paper, the character and interpretation of the facies are first documented in terms of processes and environment: the distribution of these facies across the basin at different levels is then analysed to develop models for correlation and the paleogeographic evolution of the basin.

\section{Study area}

Coal mining has been a commercial activity in the Svalbard archipelago (Fig. 1) for over a hundred years, with the most productive seams occurring in the Paleocene Todalen Mamber (Mb) of the Firkanten Fm (Fig. 2). This formation is the oldest unit in the Central Tertiary Basin (Fig. 2), which covers the central part of the main island Spitsbergen (Fig. 1) and comprises $1.9 \mathrm{~km}$ of Paleogene clastic deposits (Dallmann, 1999). This succession rests unconformably on the Carolinefjellet Fm (Fig. 3) which is of AlbianAptian age (Dallmann, 1999). It is estimated that about $1 \mathrm{~km}$ of sediments have been eroded, based on vitrinite reflectance data (Marshall et al., 2015). Large laterally extending outcrops of the Firkanten Fm, 


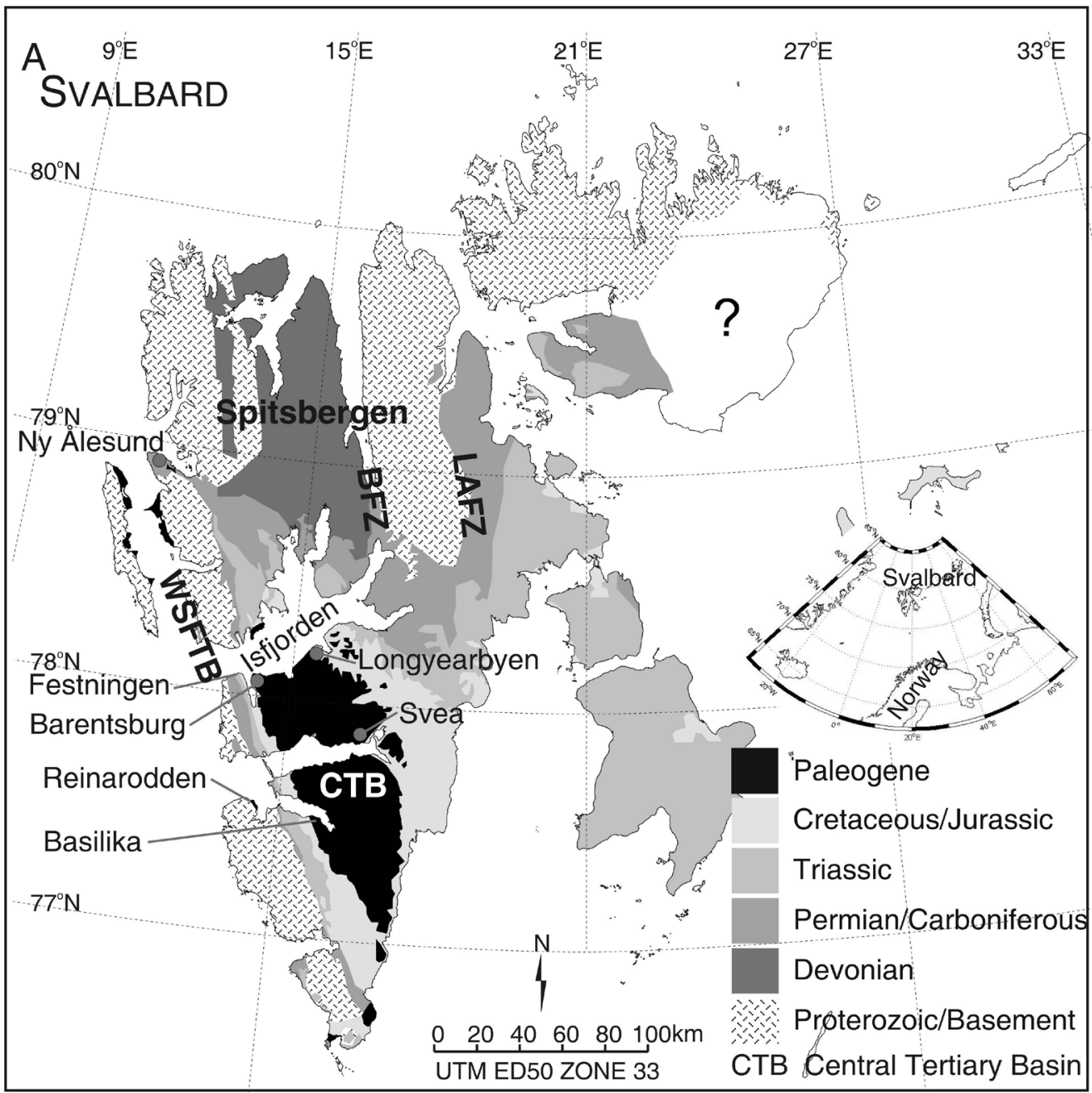

\section{B West Spitsbergen Central Tertiary Basin Fold and Thrust belt}

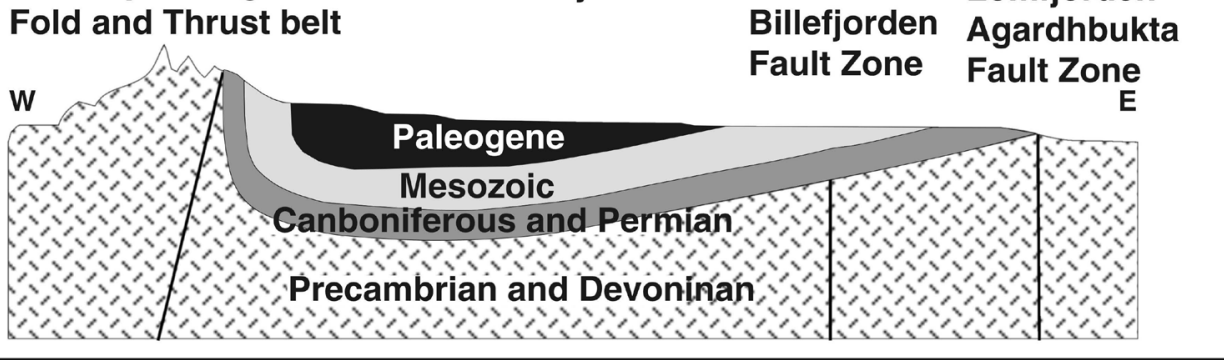

Lomfjorden-

aleogene

Precambrian and Devonínán

Figure 1 (A) Geological map of Svalbard, after Dallmann (1999). The main Paleogene strata are found in the Central Tertiary Basin (CTB) that occupies the centre of the southern part of the main island, Spitsbergen (marked in black). Marked are some of the key field sites. West Spitsbergen Fold and Thrust Belt (WSFTB), Billefjorden Fault Zone (BFZ), Lomfjorden-Agardhbukta Fault Zone (LAFZ). (B) Generalised west to east cross-section.

in all directions in the valleys around the island, give a general impression of the flat stratification of the sediments. No major channel sections or valley incisions interrupt the overall flat stratification (Fig. 3) which consists of a fine-grained lower section, of Todalen $\mathrm{Mb}$ and a sandstone-prone upper part of the Endalen Mb. The outcrops are of good quality for broad observations (Fig. 3).

A flexural foreland basin origin is now favoured for the formation of the basin (Bergh et al., 1997; Braathen et al., 1999a; Bruhn \& Steel, 2003; Dörr et al., 2013), forming as the result of crustal 


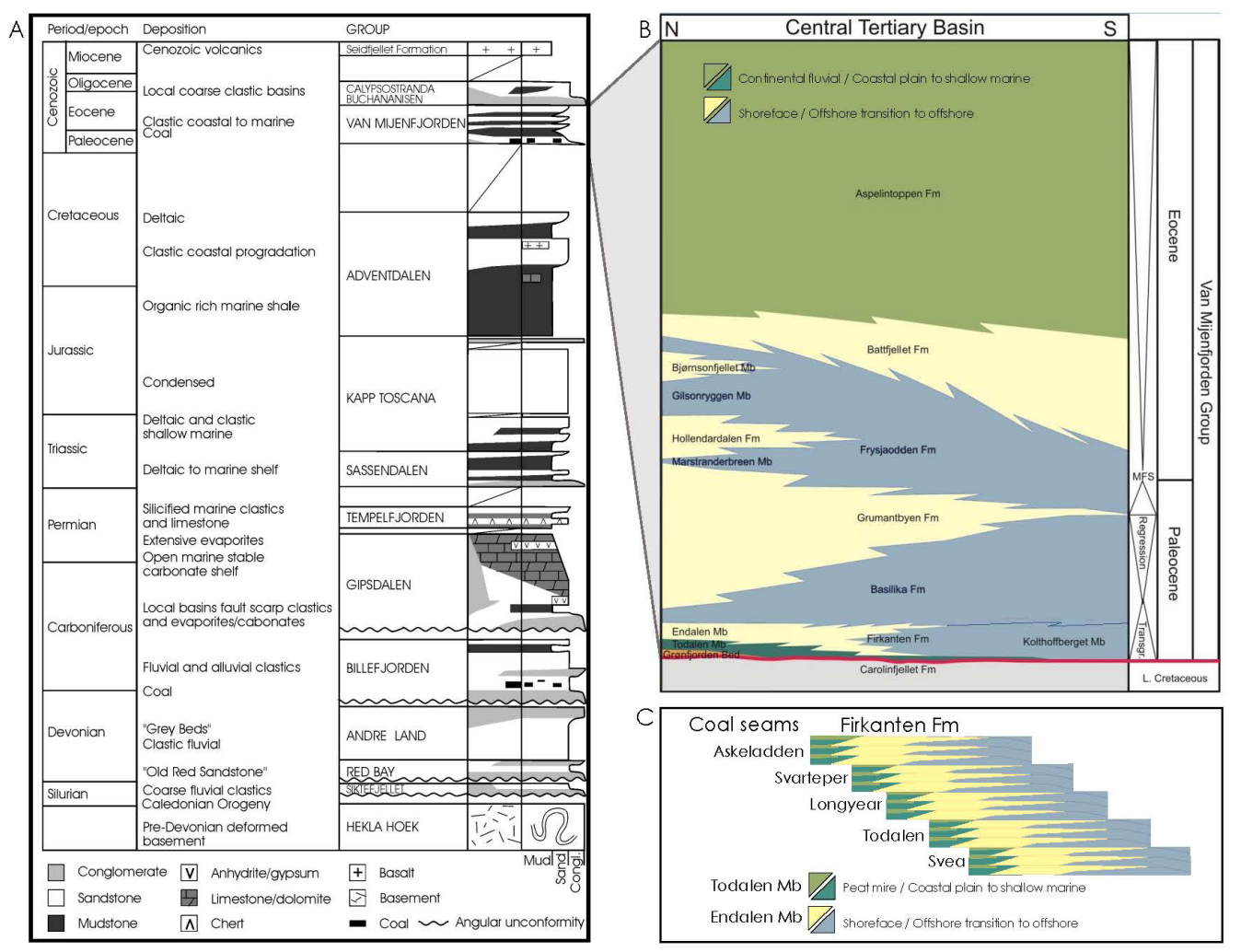

Figure 2 (A) The stratigraphy of Svalbard (modified after Worsley et al., 1986; Dallmann, 1999) with the indicated hiatus of the Upper Cretaceous between the Carolinefjellet Formation (Fm) and the Firkanten Fm. (B) The stratigraphy of the Cenozoic Van Mijenfjorden Group (Gp) in the Central Tertiary Basin of Spitsbergen, based partly on Steel et al. (1985), Dallmann (1999) and Bruhn \& Steel (2003). The focus of this study is on the lower part of the succession, the Todalen and Endalen Members (Mbs) of the Firkanten Fm. Group (Gp), Formation (Fm), Member (Mb). (C) Generalised figure of the stratigraphy of the Firkanten Fm and the relationship of the five different coal seams named by SNSK the Svea, Todalen, Longyear, Svarteper and Askeladden seams. Overall the Firkanten Fm is transgressive in an aggrading stacking pattern.

shortening between Greenlandand Svalbardassociated with theopening of the North Atlantic. The basin was bordered by the thrust front of the West Spitsbergen Fold Belt in the west and an uplifted area in the north. To the east lies the region that is now the Barents Shelf which includes a number of crustal lineaments that had formerly acted as strike-slip shear zones in Svalbard (Harland, 1997), whilst to the south the basin was open to the nascent North Atlantic (Blythe \& Kleinspehn, 1998). Fossil plant material indicates that the climate in the Paleocene and Early Eocene was warm-temperate, with a high humidity equally distributed through the year (Golovneva, 2000), even though plate reconstruction places Spitsbergen at 65-680 N at this time (Cepek \& Kruttzsch, 2001).

Previous interpretations of the Todalen $\mathrm{Mb}$ of the Firkanten $\mathrm{Fm}$ have considered the facies to represent a deltaic setting (Steel et al., 1981, 1985; Dallmann, 1999). However, a new detailed facies analysis, based on several kilometres of new core data and additional field observations, has shown that the depositional environment may be better interpreted as the deposits of a coastal plain. The new cores dating from 2002 to 2006 were made available by the Norwegian mining company SNSK (Fig. 4). The main target area for coal exploration has been between Longyearbyen and Svea, which is where most cores were drilled. The excellent core quality made it possible to investigate in detail the finer-grained parts of the succession that are poorly exposed in the field. To supplement the core data, field work was carried out in the most accessible areas in the vicinity of Svea, in Adventdalen and nearby valleys, at Ispallen, and in Reindalen for comparison to the cores; field data were also collected at Festningen, Kolfjellet and Basilikaelva (Fig. 4). For information on the facies assemblages of the southern and western part of the 

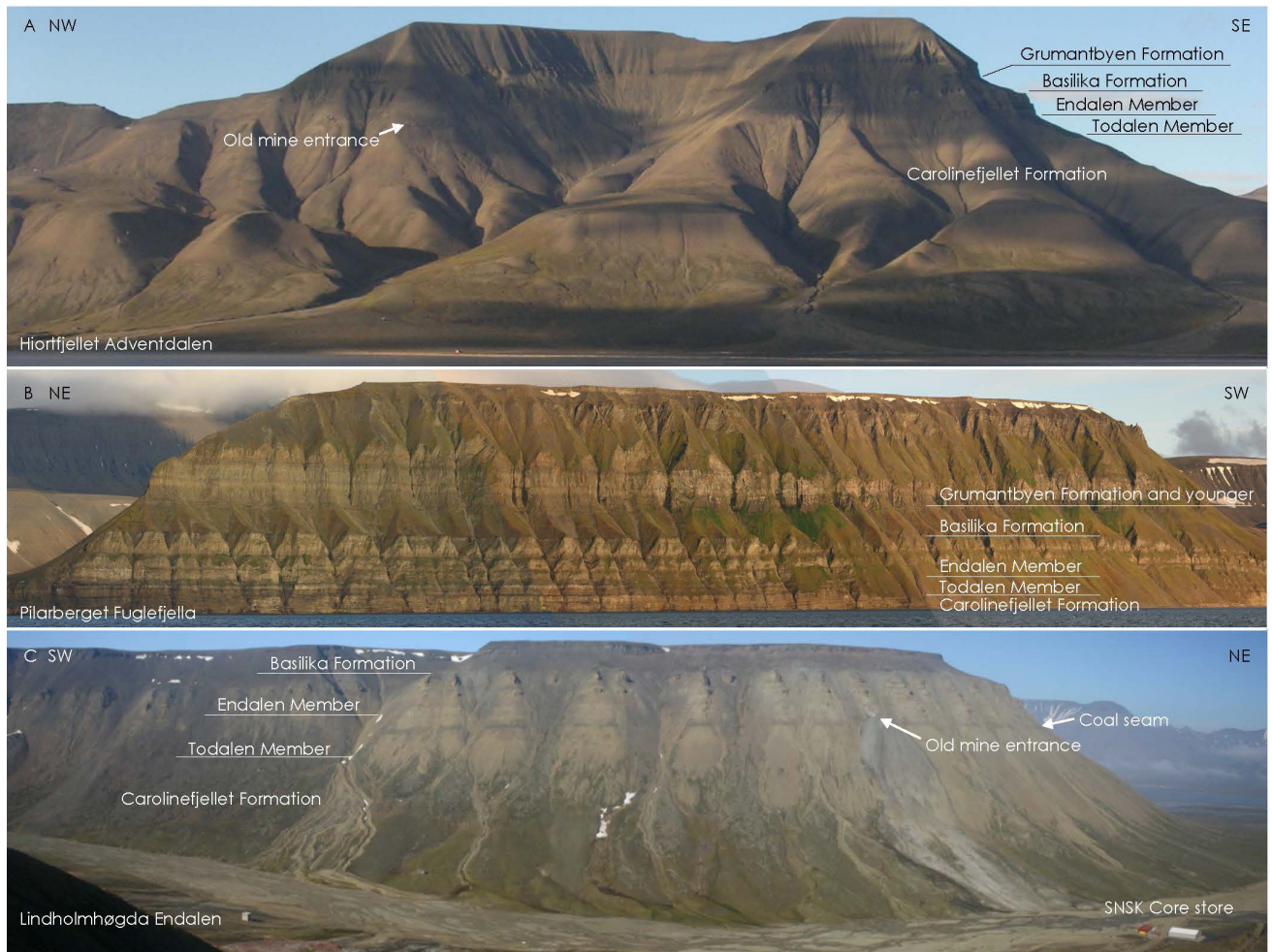

Figure 3 Impression of the general lateral extent of the near-horizontal strata of the Firkanten Fm. (A) Hiorthfiellet north of Adventdalen (2.5 km across). (B) Fuglefjella between Bjørndalen and Grumantbyen (3 km across). (C) Lindholmh øgda in Endalen east of Longyearbyen (2.5 km across). For location, see Fig. 4. The marked sandstone cliff of the Endalen Member (Mb) can be clearly seen, and further up the Grumantbyen Fm. Below the Endalen Mb there are the softer coals and shales of the Todalen Mb. The Basilika Fm is also made up of soft sandy mudstone and muddy sandstones. No fluvial channels or valley incisions are observed.

basin selected references were used (e.g., Nagy, 1966; Kellogg, 1975; Dallmann, 1999; Nagy, 2005).

All data were considered for the facies analysis and re-classified according to the facies scheme. The same was done for the correlation and the paleogeography. However, only the longer more vertically consistent logs were used in the final correlation diagrams. The shorter more sporadic data points were typically recorded in the field from the Todalen Mb. In addition, there were observations of the facies related to the coal deposits from the mines in both Svea and Longyearbyen and SNSK contributed with some chemical data. To be able to cover some of the more remote places reference data were used and re-interpreted and re-classified into the new facies scheme in order to be comparable to the other dataset.

The data available and the quality have been focused in the eastern area around the Svea mine, since this area has had the most extensive drilling campaign. The interpretation is therefore also more detailed in this area. The interpretation is extended outside of the drilled area by field and reference data, which both are of much lower quality especially in the Todalen Mb. 


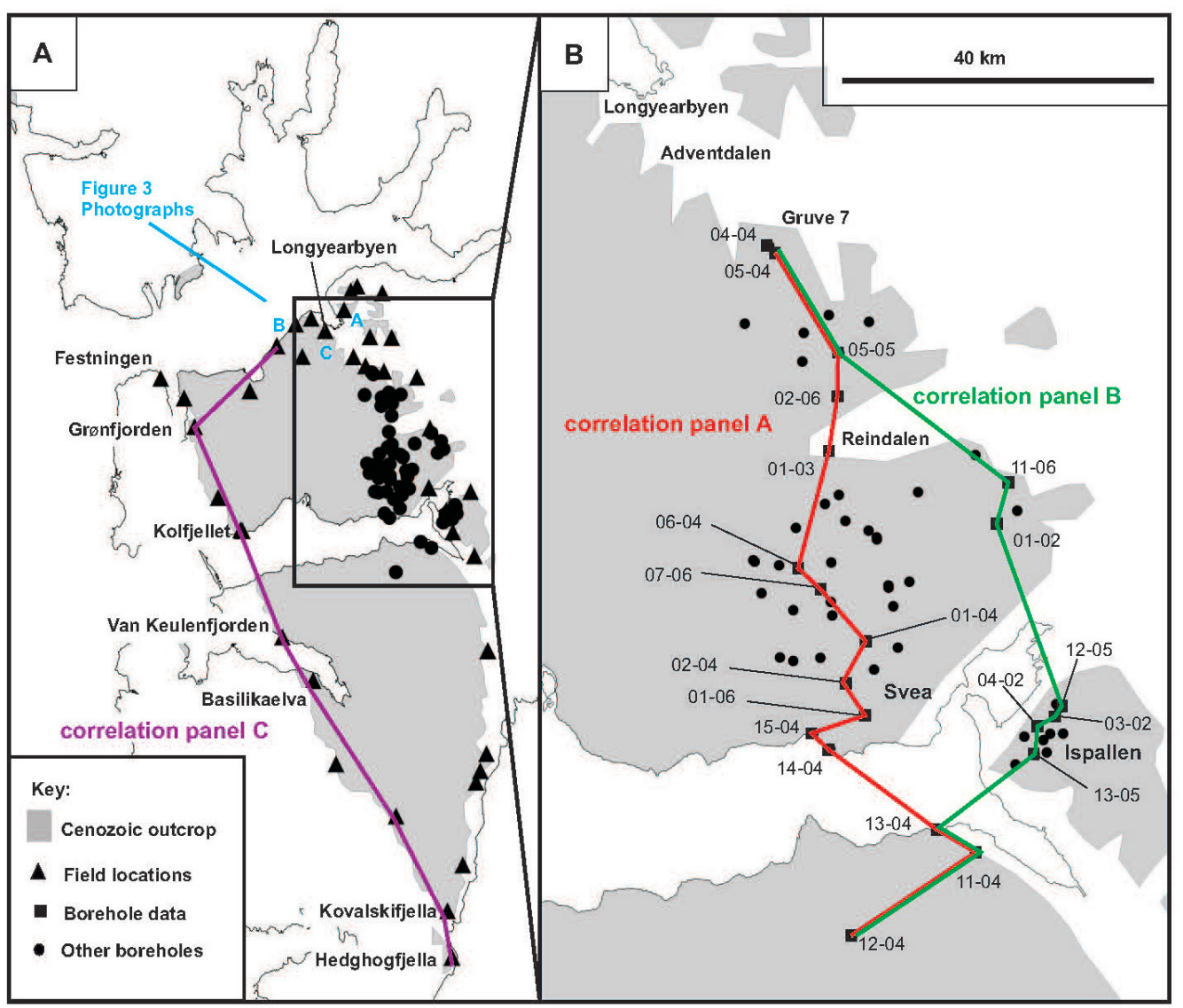

Figure 4 (A) Outline of the Paleogene strata of Svalbard in the Central Tertiary Basin (Dallmann, 1999) with the locations of data used in this study. All data were used in the facies analysis and the stratigraphic correlation including paleogeographic reconstructions. However, some of the field locations were not possible to log in vertically consistent sections and could therefore not contribute to the correlations. For overview see Fig. 1. The regional correlation panel C can be found in Fig. 15. Location of photographs in Fig. 3 indicated. (B) The borehole data from the eastern part of the basin, used to construct the correlation panels A (Fig. 13) and B (Fig. 14).

\section{Facies description and interpretation}

Graphic sedimentary logs from core and outcrop data through the Firkanten Fm have been used as the basis for constructing a facies scheme comprising 10 facies, subdivided into 45 subfacies and grouped into 4 facies associations (Tab. 1). The four facies associations are; FA1 vegetated subaerial to marginal marine, FA2 back barrier tidally influenced lagoon, FA3 foreshore barrier bars, and FA4 shoreface.

The Todalen $\mathrm{Mb}$ is heterolithic and consists mainly of very fine sandstone, siltstone, mudstone, and coal (facies K, Mk, Sk, Sr, Sh and Ms, Table 1) of FA1, FA2 and FA3. In the western part of the basin (Fig. 4) the Todalen $\mathrm{Mb}$ is underlain by a fluvial conglomerate of the Grønfjorden Bed (subfacies Cgp1, Table 1). The Endalen $\mathrm{Mb}$, which is the upper part of the Firkanten $\mathrm{Fm}$, consists mainly of homogeneous fine-grained sandstone (facies Sws, SI and partly Sb, Tab. 1) of FA3 and FA4, which is typically several tens of metres thick, for example where it forms cliffs in the type section in Endalen on the south side of Adventdalen. Only the lower part of the Basilika Fm has been included in this study and is mainly represented by facies Sb (Table 1) FA4.

The facies were described objectively and interpreted both independently and in context. The description and interpretation were made unbiased by previous interpreters. However, the comparison 


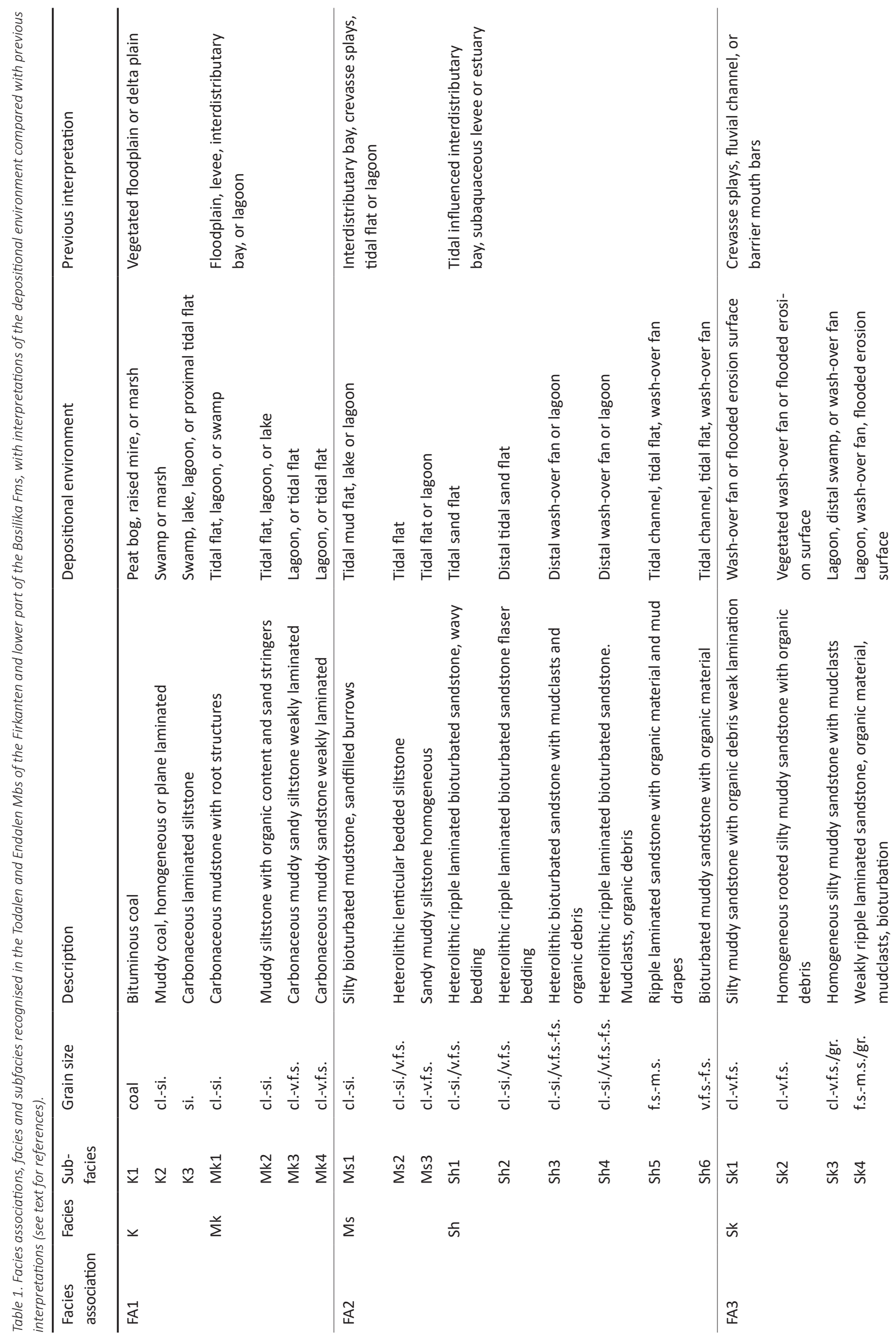




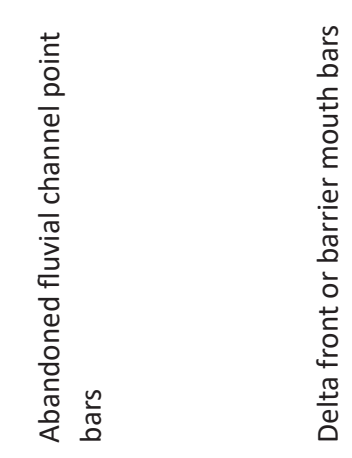

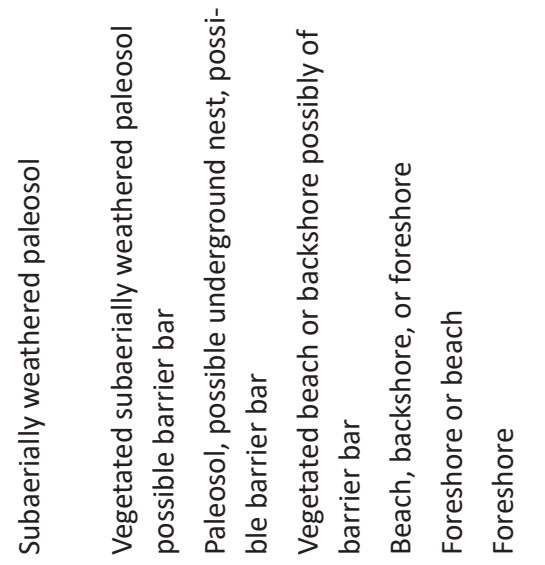
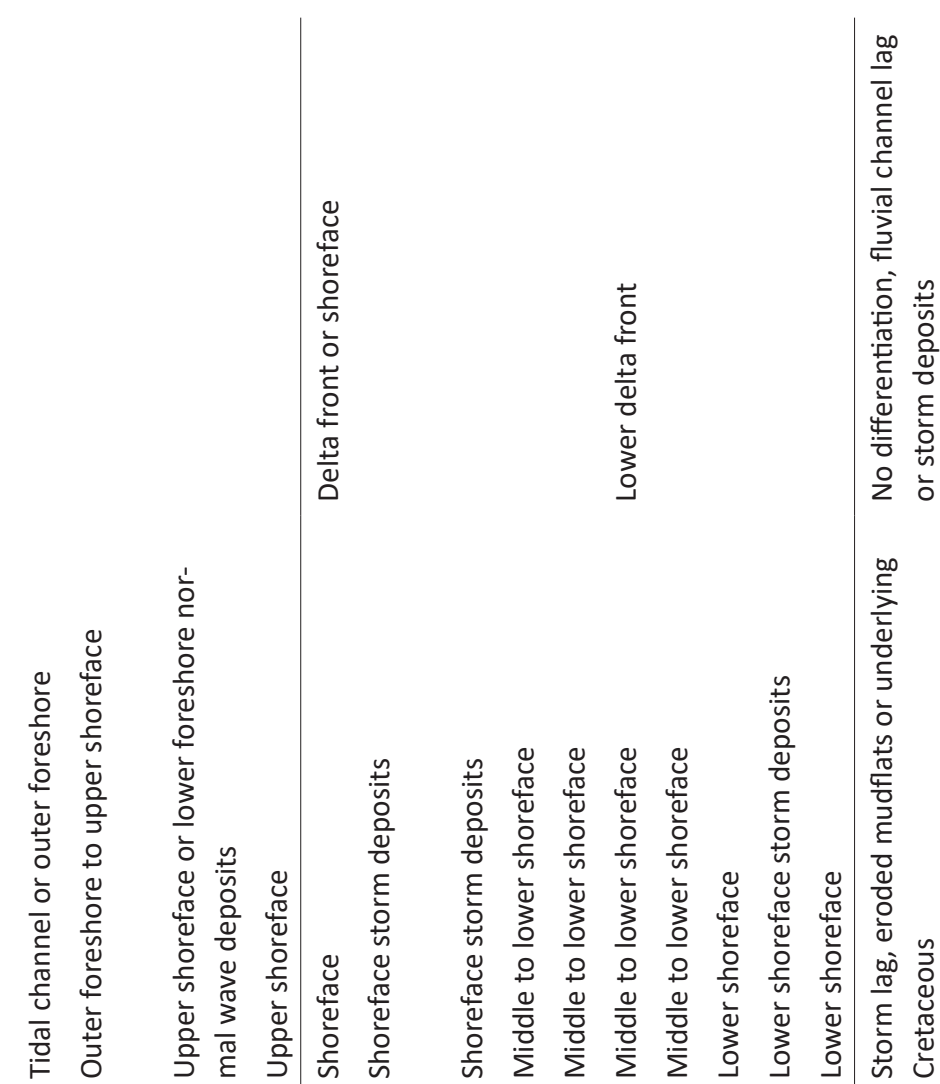

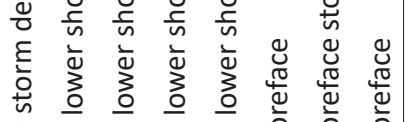

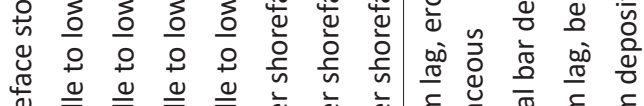

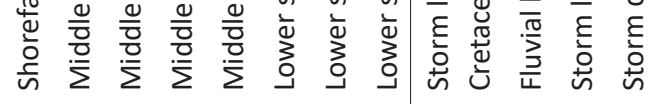
跤
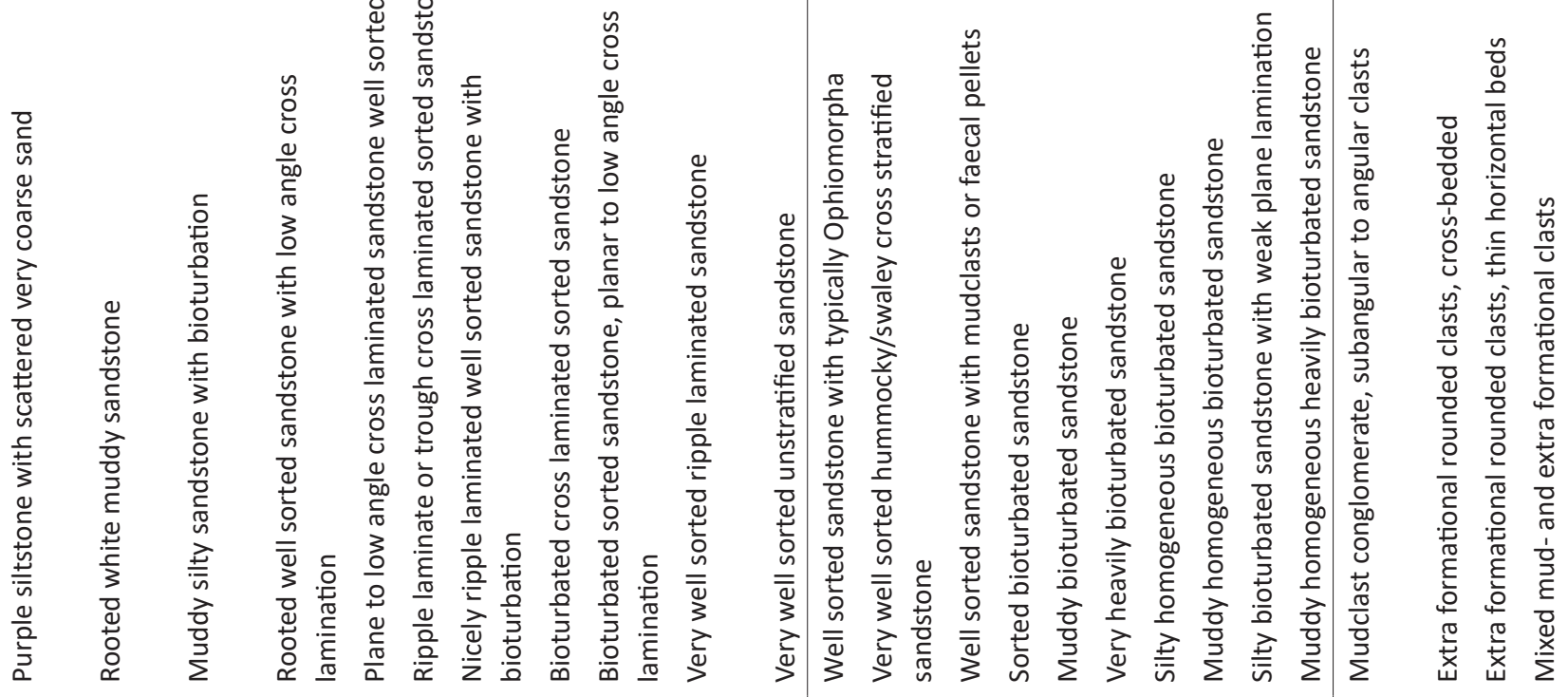

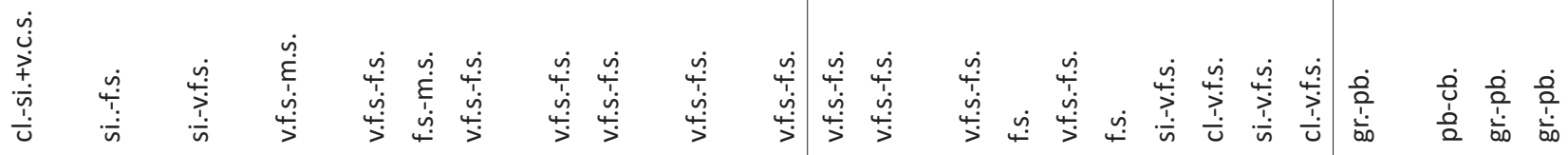

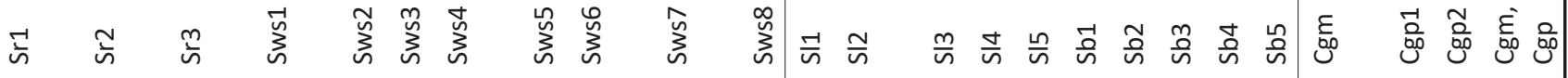
is 兴
点 $\frac{\dot{0}}{\frac{0}{00}}$ 
to previous results is presented later in this paper. The general observations are mostly aligned except for a few critical understandings of the deposition. These key elements especially are the development of coal-forming environments, and the identification of different types of conglomerates.

\section{Facies K: Coal (FA1)}

In addition to pure coal seams, this facies includes muddy, silty coal and carbonaceous silty mudstone (Fig. 5). Beds are homogeneous or plane-parallel laminated, the bed thickness varies from a few centimetres to several metres and may include clay-rich splits. The thickest coal deposits are almost five metres thick in Svea Nord mine (Fig. 4) where there is on-going extraction of a coal seam that extends over tens of square kilometres. The coal seams are more extensive and thicker on the eastern side of the basin.

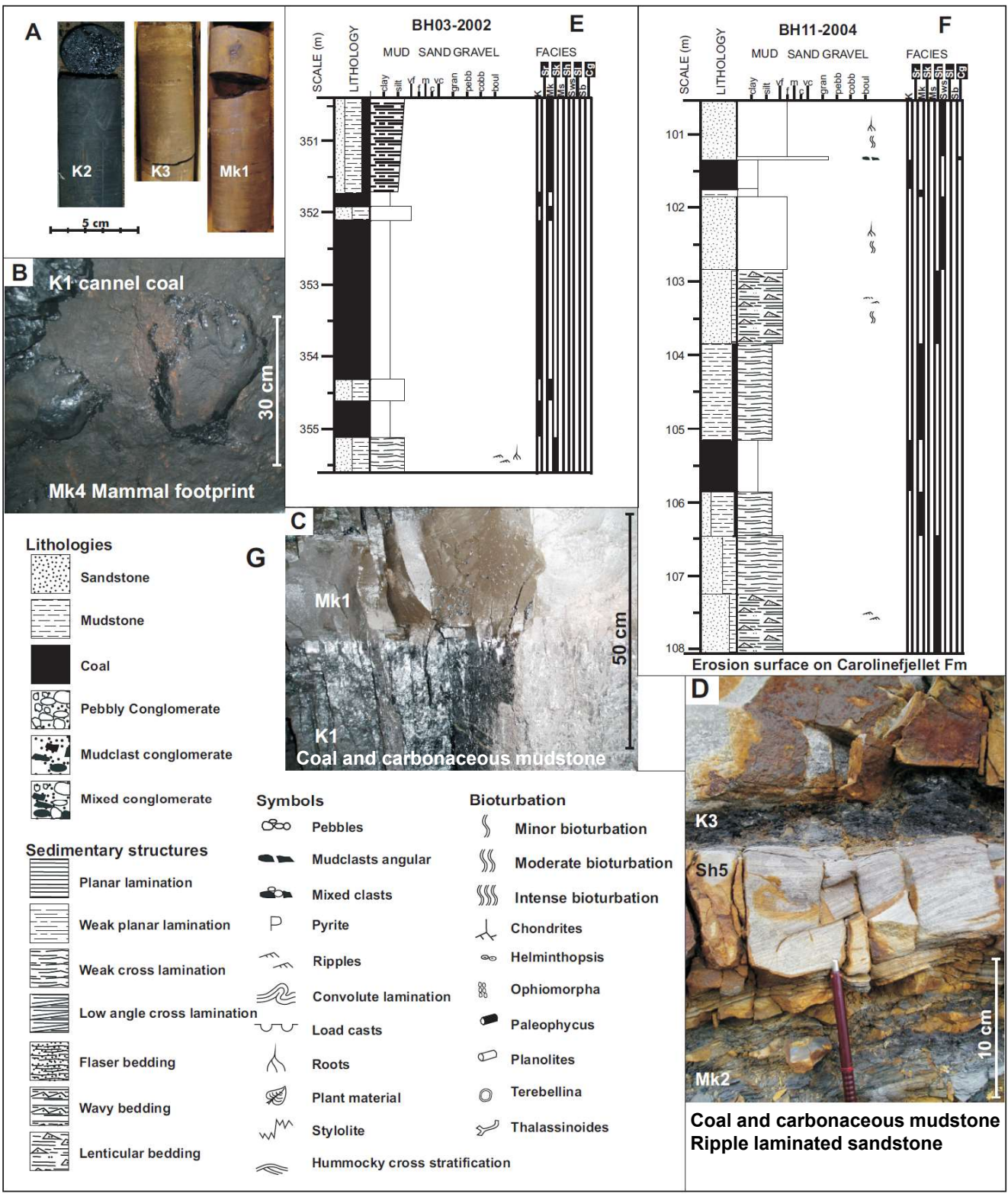

Figure 5 Core photos, field photos and graphic logs of FA1 vegetated subaerial to marginal marine, representing peat mire, lagoon, palaeosol and muddy tidal flat. (A) Core photos of muddy coal and carbonaceous mudstone. (B, C, D) Field photos of coal in the mine and field, mammal footprints of Pantodont in cannel coal from Mine 7 Longyearbyen. (E) Log of facies Mk carbonaceous mudstone. (F) Log of facies K coal. (G) Legend for logs in Figs 5, 7, 8 and 9. 
Coal seams are poorly exposed in outcrops, but recovery in the drilled cores is excellent. The coal rank is high-volatile bituminous and in general has a low ash and sulphur content ( $<2 \%$ sulphur when ash is $<10 \%$ ) but there are variations in these values (Manum \& Throndsen, 1978). The sulphur content has been reported as being higher near the base and top of the coal seams. Coal seams are black or very dark brown in colour, and they mostly comprise humic coal except for the presence of sapropelic (cannel) coal which is found at the top of some coal seams in association with pyrite. The basal contacts of the beds are typically transitional from finer-grained facies below and have sharp or erosive contacts with overlying sandstone beds. Facies $\mathrm{K}$ is associated with facies Mk, Ms and Sr. The coal primarily contains material from vascular plants such as conifers Cupressaceae Taxodiaceae and rare Podocarpaceae from wet forested mires (Cmiel \& Fabianska, 2004).

A detailed analysis of a 3.05 m continuous section through the Svea coal seam (Fig. 6) has revealed that apart from two clastic splits within the seam, the non-organic content is very low, at less than $1.0 \%$. Pyrite only occurs associated with parts of the seam that are more clastic-rich. Vitrinite is the most common maceral, averaging 57\%, although the proportion varies from $12 \%$ to $100 \%$. Inertinite proportions generally mirror the vitrinite percentage, ranging from $0 \%$ to $84 \%$ and averaging $40 \%$, whilst the liptinite, which averages $3 \%$ makes up between $0 \%$ and $10 \%$ of the macerals present.

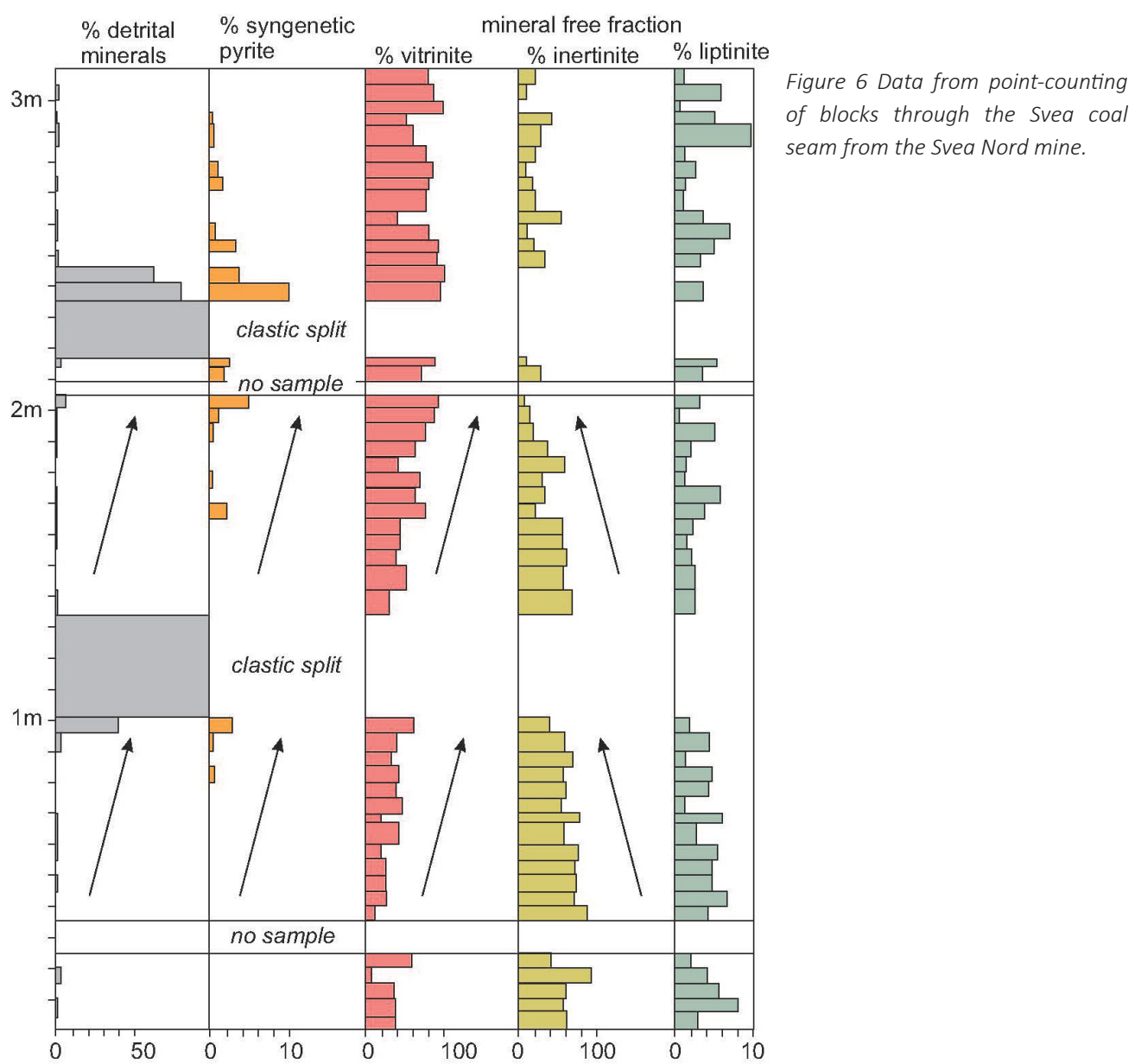




\section{Interpretation of facies K}

The thick, laterally extensive, coal deposits are derived from areas where substantial vegetation growth, standing water and low inorganic input allowed peats to develop in a setting where mire growth kept pace with a rising base level (Ward, 1984; McCabe, 1984; Diessel, 1992; Bohacs \& Suter, 1997). The generally low content of clastic material and sulphur in the coal suggests raised, ombrotrophic origins for portions of the mire, (e.g., Clymo, 1987; Staub, 1991; Diessel et al., 2000; Davies et al., 2005) Peatforming mire types vary as a function of accommodation rates (Diessel et al., 2000; Diessel, 2007; Jerrett et al., 2011a, b). Accommodation in mires is generated by the water table (= base-level) rising relative to the sediment surface (Ingram, 1978; Clymo, 1984; Allen, 1990). The rate of organic production is the sedimentation rate in a peat mire. When the accommodation rate is less than organic productivity, the rate of peat accumulation is effectively limited. Under conditions where rainfall exceeds evapotranspiration, the low hydraulic conductivity of peat allows the mire to utilise the excess moisture to locally dome the mire water table by up to $20 \mathrm{~m}$ above the regional water table (Bruening, 1990; Winston, 1994; Diessel, 2007). These ombrotrophic mires, effectively generate their own accommodation, and thus peat accumulation rates can more closely match organic productivity. Conversely, when the accommodation rate outpaces organic productivity, peats accumulate in lowlying, rheotrophic mires, where clastic sediments (depending on availability) take advantage of excess accommodation that is not filled by in situ accumulation of organic material (Bohacs \& Suter, 1997; Diessel \& Gammidge, 1998; Diessel et al., 2000). Since an ombrotrophic mire or peat bog is raised, it is sensitive to climate and depending solely on precipitation for water input. However, it is protected from the input of clastic material, since there is no input from streams or springs. An exception is during episodes of marine flooding that resulted in clay-rich splits and associated pyrite. The local occurrences of sapropelic coal are likely to have formed from the settling of suspended algal or bacterial material in stagnant swamps and lagoons under anaerobic conditions (McCabe, 1984). The occurrence of sapropelic coal on top of the humic coal may be the result of the initial stage of flooding of the mire complex.

\section{Facies Mk: Carbonaceous mudstone (FA1)}

Carbonaceous, muddy siltstone and occasional muddy fine sandstone (facies Mk) commonly occurs associated with facies $\mathrm{K}$. The beds vary from a few centimetres to more than a metre thick, are plane-parallel laminated or homogeneous and the colour is dark brown to black due to the very high organic content (Fig. 5). Organic material also occurs as fragments of pure coalified clasts and some root structures occur.

\section{Interpretation of facies Mk}

The high organic content and the close association of this facies with coal suggest that this facies formed in settings where peat was accumulating but the clastic input was too high to form pure coal (Bohacs \& Suter, 1997). The muddy character suggests a low energy level for deposition while the sulphur content in associated coal seams indicates some marine influence. The characteristics of this facies are consistent with settings such as vegetated supratidal swamps and marshes protected by barrier bars from waves, tides and storms but still influenced by marine or brackish water (Reading \& Collinson, 1996). It could also have been deposited in a marginal part of an interdistributary bay setting if this was the context but it would not explain the increase in sulphur content. 


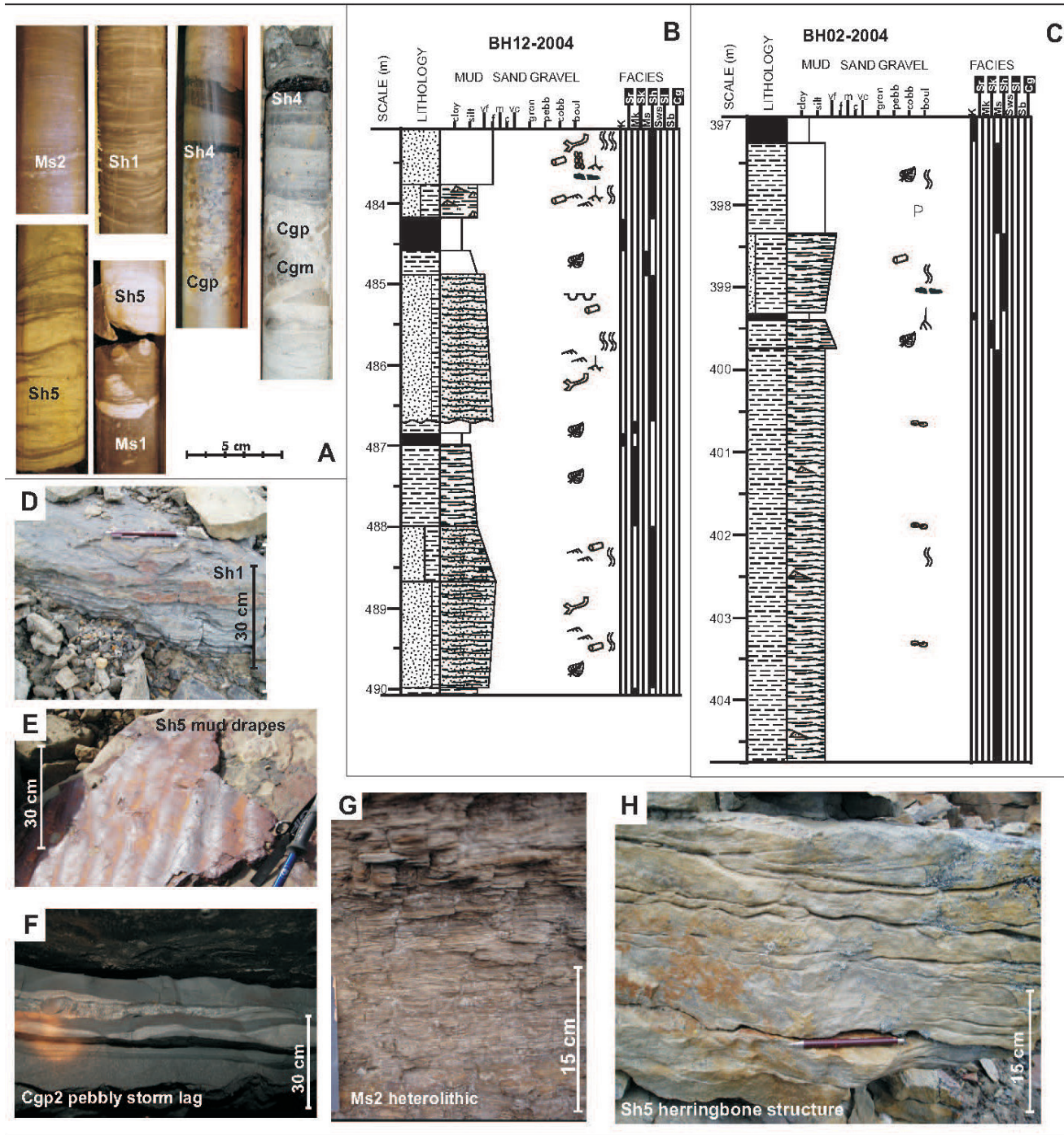

Figure 7 Core photos, field photos and graphic logs of FA2 back barrier tidally influenced lagoon representing bioturbated muddy sections of tidal flat and lagoon. (A) Core photos of tidal deposits and different conglomerate units; note $\mathrm{cm}$-scale and sand-filled burrows. (B) Log of facies Sh heterolithic sandstone and mudstone. (C) Log of facies Ms dark-grey muddy siltstone. (D-H) Field photos of tidal features such as mud drapes, herringbone structures and flaser bedding; pebbly storm lags in muddy siltstone representing wash-over fans on a tidal flat.

\section{Facies Ms: Dark-grey muddy siltstone (FA2)}

This dark-grey, sandy, muddy siltstone is commonly associated with facies Sh. The beds are horizontally laminated in part but are mostly homogeneous with bioturbation in the form of large (cm-scale) sand-filled burrows (Fig. 7). Lenses of ripple-cross-laminated sandstone form lenticular bedding. The beds may be up to a metre in thickness, although where interbedded with facies Sh they are generally only a few centimetres thick. The organic content is low but this facies occurs in association with the organic-rich facies Mk.

\section{Interpretation of facies Ms}

The lenticular bedding suggests a variable energy, tidally influenced environment and the sandfilled burrows may form on mudflats which partially dry out at low tide and fill with sand during the rising tide. The homogeneity may be the result of intense bioturbation destroying many primary 
sedimentary structures. A low-energy setting such as the proximal part of tidal mudflats or sheltered tidally-influenced lagoons may be a likely environment of deposition (Reinson, 1992). Silty mudstone with low organic content has also previously been described from the Firkanten Fm by Nagy (2005), who, based on the restricted foraminifera fauna, interpreted these as lagoon deposits. The bioturbation and the variable energy are strong evidence for a marine environment.

\section{Facies Sh: Heterolithic sandstone and mudstone (FA2)}

Facies Sh comprises a range of subfacies of heterolithic interbedded sandstone and mudstone with flaser, wavy and lenticular bedding (Tab. 1). Along with Ms, Sh is the most common facies in the Todalen Mb and can make up beds of up to several metres thickness. The sand is well sorted, very fine to fine, rarely coarser, and it is commonly bioturbated with sand-filled burrows (Fig. 7); Teredolites was observed in Mine 7 in a bed overlying the coal, while root structures occur in places. The lamination is disturbed by bioturbation, loading and soft sedimentary deformation but ripple lamination occurs frequently. Small-scale herringbone structures with mud-drapes are observed both in core and outcrop and mudclasts and organic debris are present. Facies Sh occurs associated with both facies Mk and Ms.

\section{Interpretation of facies Sh}

The alternation of sand and mud indicates the rapidly changing energy level of a tidal environment, whilst herringbone structures and mud-drapes are also strong indicators of tidal conditions (Reineck \& Wunderli, 1968; Dalrymple, 1992). Organisms would have been active in the mud during quiet periods and later the burrows were filled with sand during the rising tide. Teredolites are created by marine bivalves that typically bore into woody organic material (Pemberton et al., 1992). The wide range of subfacies (Table 1) represents different zones in the tidal-flat environment characterised by different energy levels and water depths. Mud deposits are normally expected to represent the more landward tidal-flat setting whilst the grain size or the sand/mud ratio increases gradually seawards (Dalrymple, 1992). The less muddy sections possibly represent minor tidal channels and tidal bar complexes.

\section{Facies Sk: Organic-rich muddy sandstone (FA3)}

Facies Sk is made up of predominantly grey to dark-grey, very fine sandstone which is very poorly sorted and mixed with mud, silt and organic debris (Fig. 8). The different subfacies of Sk show variable amounts of mud and organic debris (Tab. 1). The beds are up to $2 \mathrm{~m}$ thick but normally less than $0.5 \mathrm{~m}$ and primary structures are mostly absent or disturbed, but weak planar and ripple lamination occur. This facies is in places overlain by coal. Specific trace fossils are rarely identified but root structures and possible Thallasinoides and Scalarituba have been observed in outcrops. Facies Sk occurs most frequently at the base of the Todalen Mb in association with facies Cgm, K, Ms or Sh. Thin-sections of sandstones of this facies reveal the presence of primary glauconite, which shows no sign of oxidation and is commonly deformed between other grains as a result of compaction (Fig. 8).

\section{Interpretation of facies Sk}

The combination of marine indicators (trace fossils and glauconite) and the terrestrial characteristics (roots and high organic content) suggest a continental to marginal marine environment. Glauconite forms in marine environments with low clastic sediment input (Prothero \& Schwab, 1996) and is concentrated during periods of sea-level rise (Johnson \& Baldwin, 1996). The glauconite grains 


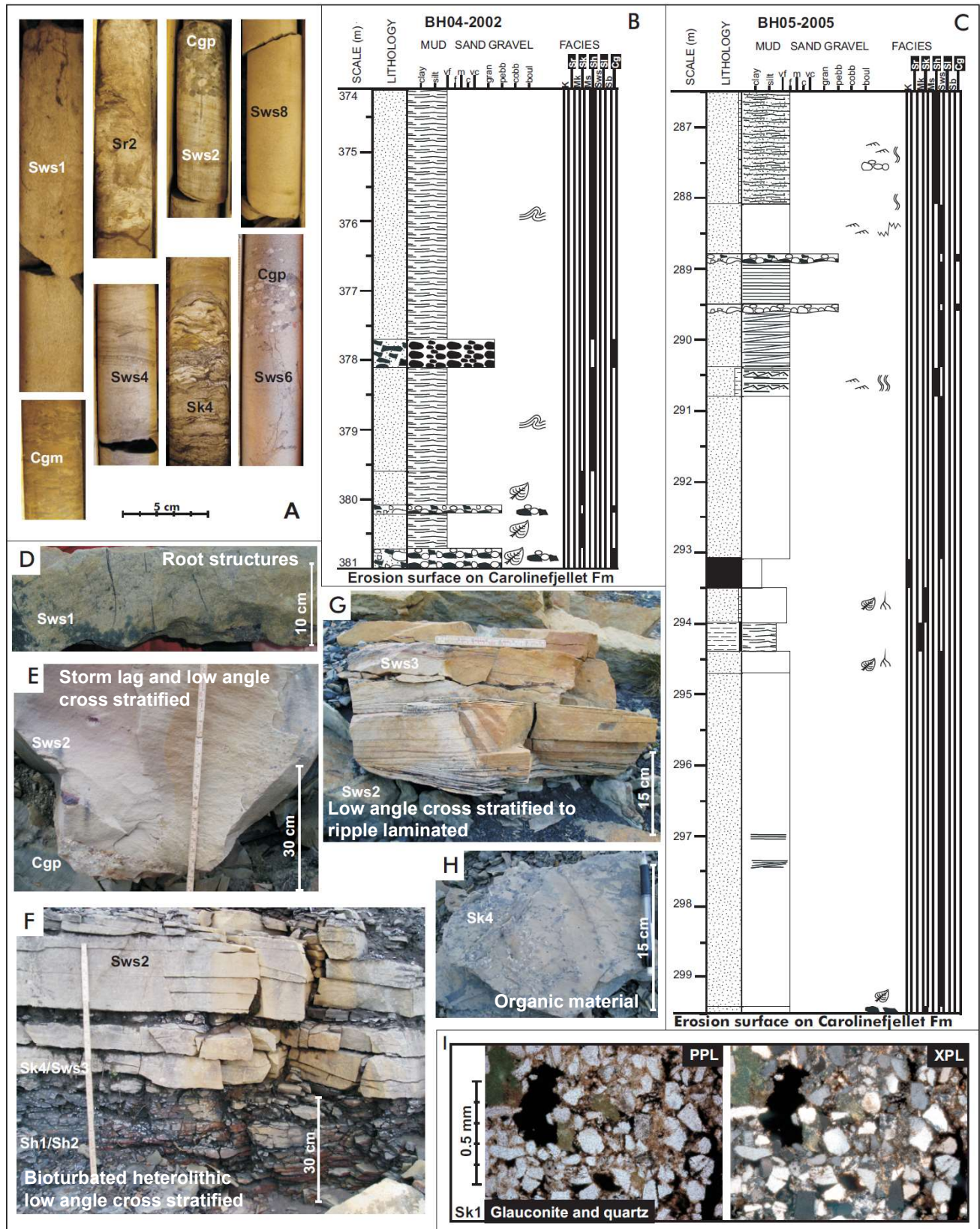

Figure 8 Core photos, field photos and graphic logs of FA3 barrier bars representing well-sorted sandstone of foreshore/ upper shoreface and wash-over fans/erosive flooding surface. (A) Core photos of foreshore/upper shoreface well-sorted sandstone, conglomerate layers, palaeosol represented by Sr rooted sandstone palaeosol and Sk organic-rich sandstone in a wash-over. (B) Log of facies Sk organic-rich muddy sandstone. (C) Log of facies Sws well-sorted sandstone. (D-H) Field photos of homogeneous, low-angle cross-stratified and bioturbated sandstone. (I) Photomicrograph of glauconitic quartzitic sandstone of facies Sk organic-rich sandstone.

were incorporated into this facies, but since the grains show no signs of oxidation, their origin was most probably in contemporaneous marine environments. It is not likely that the glauconite was reworked from the underlying Carolinefjellet Fm. Facies Sk is primarily but not exclusively found at the base of the Paleocene succession situated on the unconformity to the underlying Carolinefjellet Fm. The characteristics and association with mudclast conglomerate (facies Cgm) suggest that this facies may represent flooding events, such as wash-over fans built into a lagoon (Reinson, 1992). These deposits may be bioturbated between storm events and can also be vegetated (Reading \& Collinson, 1996), resulting in a thin coal overlying the unit (Reinson, 1992), an association found in the Todalen Mb. 


\section{Facies Sr: Rooted fine sandstone (FA3)}

Facies Sr is typically a silty very fine to fine sandstone with some organic material and scattered coarser grains. Beds are grey, purple, yellow, white or brown in colour. The layering is disturbed by abundant root structures and although there are no identified trace fossils, bioturbation is present (Fig. 8). Bed thicknesses are less than $0.5 \mathrm{~m}$ and the lower boundary is commonly transitional from the Sk or Sws facies. Facies Sr is rare but when present it is overlain by coal.

\section{Interpretation of facies $\mathrm{Sr}$}

The leached appearance of facies Sr, roots, and association with coal seams suggest that it is a palaeosol. Bleached horizons overlain by coal have been termed gleyed soils associated with paludisation (Retallack, 2001), formed as a hydric soil which represents a water-saturated anaerobic surface upon which the coal-forming vegetation grew (Huddle \& Patterson, 1961; Collinson, 1996). Leaching can also be caused by the acids from the mire (McCabe, 1984). The original process of deposition of facies $\mathrm{Sr}$ is difficult to recognise because the layering is disturbed but the close association with Sk and Sws facies suggests that Sr might have formed in a similar way.

\section{Facies Sws: Well-sorted sandstone (FA3)}

This facies comprises well-sorted, grey to light grey, clean sandstone of very fine to fine grain size. Pebbles, mudclasts and organic material occur in places. The grains are predominantly quartz, but fresh, non-weathered glauconite can make up to $5 \%$ of the rock. Bed boundaries are typically sharp and generally this facies shows few sedimentary structures (Fig. 8) except poorly preserved ripple lamination, low-angle cross lamination, and plane-parallel lamination. Root structures occur only in the uppermost part of some beds and are generally associated with facies Sr. In places, beds are bioturbated showing Skolithos ichnofacies such as Ophiomorpha (typically lined, Nagy et al., 2016) and Planolites. Facies Sws is found predominantly in the upper part of the Todalen Mb and throughout the Endalen $\mathrm{Mb}$.

\section{Interpretation of facies Sws}

The well-sorted and mature character of the sandstone beds indicates deposition in a moderate- to high-energy shallow-marine environment with extensive reworking. A marine environment is also indicated by the fresh grains of glauconite. The structures in facies Sws are typical for foreshore/ beach/backshore and the uppermost part of the shoreface (Walker \& Plint, 1992; Reading \& Collinson, 1996). Plint \& Norris (1991) interpreted similar deposits as beach to backshore deposits. The Skolithos ichnofacies is typical of the upper shoreface and the lining of the burrows indicates a soft, sandy substrate (Pemberton et al., 1992). Nagy et al. (2016) has looked the Ophiomorpha assemblage and describes the environment as barrier bar to shoreface. In this depositional setting normal fair-weather wave action results in well-sorted sand, while storm events will at times bring in coarser sediments and result in localised erosion of the coastline. The presence of roots indicates vegetation on a beach and facies Sws is therefore interpreted as the deposits of a beach with adjoining barrier bars/islands and foreshore deposits. 


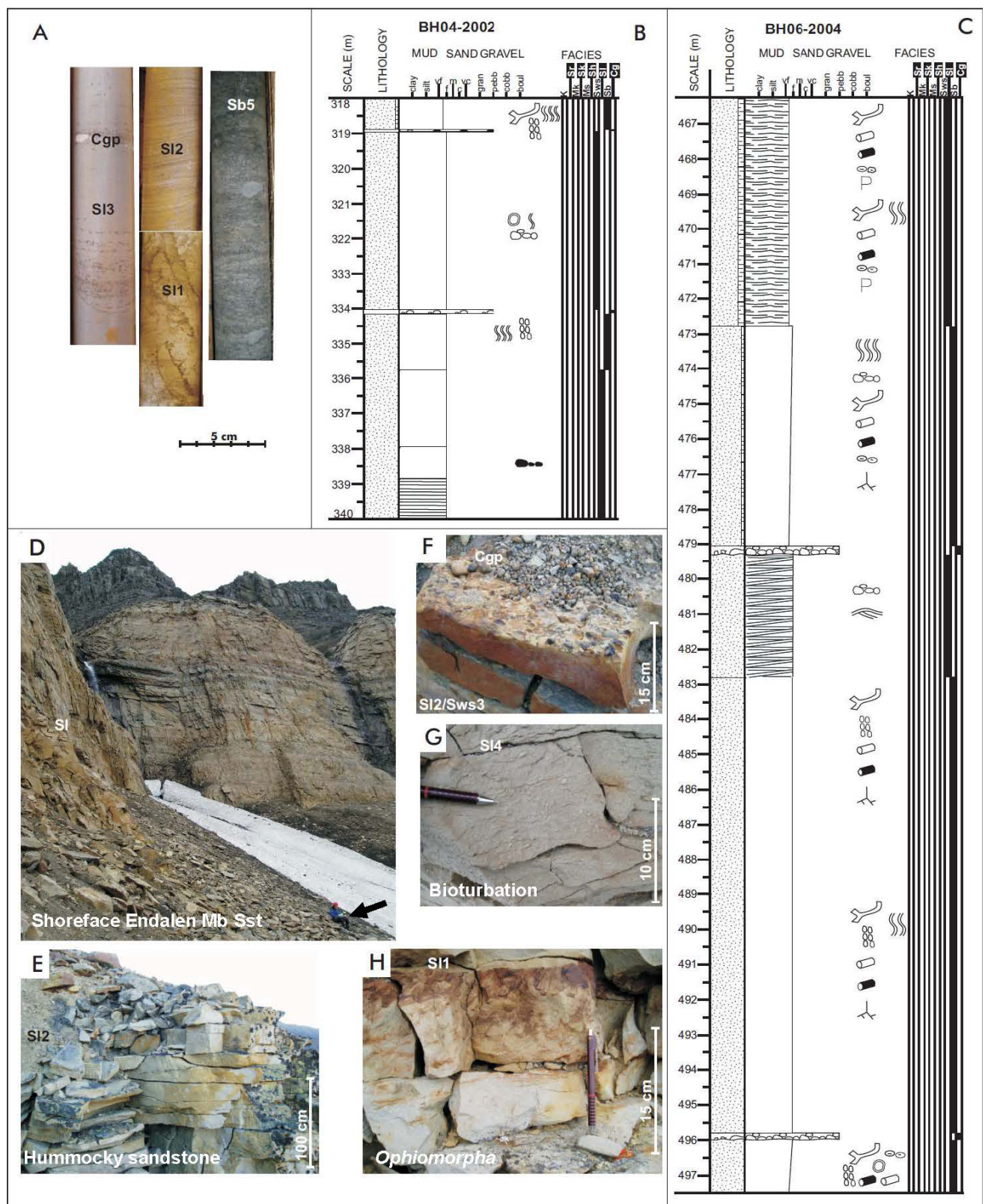

Figure 9 Core photos, field photos and graphic logs of FA4 shoreface representing shoreface to lower shoreface of well-sorted sandstone to muddy bioturbated sandstone. (A) Core photos of storm-deposited well-sorted shoreface to muddy bioturbated lower shoreface with large-scale Ophiomorpha. (B) Log of facies Sl laminated sandstone. (C) Log of facies Sb bioturbated sandstone. (D-H) Sandstone with hummocky cross-stratification, Sl laminated sandstone with bioturbation (cf. Planolites, Ophiomorpha and Terebellina) and conglomerates representing beach storm deposits and flooding surfaces.

\section{Facies SI: Laminated sandstone (FA4)}

This light grey to grey sandstone is very well sorted with weakly developed, hummocky and swaley cross-stratification, current ripple lamination, and planar lamination (Fig. 9) seen in core. The interpretation of the lamination seen in core, as hummocky or swaley cross-stratification, is confirmed by outcrop observations where these structures are in places overlain by wave ripple lamination. The beds are laterally continuous in the field. Glauconite is present within many beds and sub-rounded mudclasts occur either scattered or in distinct laminae. The beds are commonly bioturbated, typically by 
Ophiomorpha, Thallasinoides, Planolites, Palaeophycus and Terebellina, with some of the traces showing evidence of mud lining of the burrows.

\section{Interpretation of facies SI}

The presence of hummocky and swaley cross-stratification indicates deposition in high-energy shallow-marine conditions associated with storm activity (Leckie \& Walker, 1982). The mudclasts would be the products of erosion during storm events and deposition as laminated storm deposits (Reineck \& Singh, 1972). The trace fossil assemblage (Skolithos ichnofacies, Pemberton et al., 1992) is typical of moderate to high-energy shallow-marine environments, including storm-influenced shelf settings (Ekdale et al., 1984) and the clay lining of the burrows indicates a soft, sandy substrate (Pemberton et al., 1992). This association of characteristics suggests that this facies was deposited in a lower shoreface setting close to fair-weather wave base (Walker \& Plint, 1992). However, Plint \& Norris (1991) considered similar sand-rich facies to be middle to upper shoreface deposits. The horizons of mudclasts are probably storm-generated (Reineck \& Singh, 1972).

\section{Facies Sb: Bioturbated silty sandstone (FA4)}

Facies Sb typically occurs overlying facies $\mathrm{SI}$ and is found in the upper part of the Endalen $\mathrm{Mb}$ and in the Basilika Fm. This facies comprises muddy, silty, grey sandstone that is homogeneously mixed by intense bioturbation identified as Ophiomorpha, Thallasinoides, Helminthopsis, Planolites, Palaeophycus, Terebellina and Teichichnus (Fig. 9), leaving faint indications of the original lamination. In core only planar lamination can be identified but hummocky and swaley cross-stratification also occurs in outcrops of this facies that are laterally extensive for tens of metres. Pebbles and granules occur scattered within beds but also as thin laminae of sub-rounded mudclasts.

\section{Interpretation of facies $\mathrm{Sb}$}

The presence of hummocky-swaley cross-stratification suggests a storm-influenced setting, with periods of relative quiescence indicated by the extensive bioturbation: these characteristics are considered typical of lower shoreface deposits (Plint \& Norris, 1991; Reading \& Collinson, 1996). The coarser material and mudclasts may be the result of coastal erosion and redeposition by storm activity (Hart \& Plint, 1989; Reading \& Collinson, 1996). A lower shoreface setting is also indicated by the Skolithos to Cruziana trace fossil assemblage (Ekdale et al., 1984; Pemberton et al., 1992; Pemberton \& MacEachern, 1995). The bioturbated muddy siltstone and fine sandstones of the Kolthoffberget Mb (Fig. 2) (Dallmann, 1999; Nagy, 2005) are considered to be a finer version of facies Sb. Similarly, facies resembling Sb occur in the Basilika Fm further up in the stratigraphy (Dallmann, 1999).

\section{Facies Cgp and Cgm: Conglomerate}

Beds and thin layers of conglomerate occur throughout the Firkanten Fm. Two types of conglomerate clasts are distinguished; round to subrounded extrabasinal clasts form subfacies Cgp and angular to subangular, largely intrabasinal mudclasts form Cgm. The lithologies of the extrabasinal clasts in Cgp are typically chert, vein quartz, grey quartzitic sandstone and metamorphic quartzite. Subfacies Cgp1 has pebble- to cobble-size clasts and occurs in cross-bedded units. It is exposed only in the western part of the basin, for example at the type locality of the Grønfjorden Bed (Fig. 10). Facies Cgp2 occurs 
filling small scours and as thin beds of well-sorted, granule- to pebble-size conglomerate. Facies Cgm is more common at the base of the Todalen $\mathrm{Mb}$ in the eastern part of the basin where granule to pebble conglomerate occurs in beds up to $0.5 \mathrm{~m}$ in thickness. There are also examples of mixtures of the $\mathrm{Cgm}$ and Cgp2.

\section{Interpretation of subfacies Cgp1}

The Grønfjorden Bed occurs at the base of the Firkanten Fm in the western part of the basin and comprises pebble to cobble size, extrabasinal, rounded clasts of facies Cgp. The sandstone and conglomerate beds in the Grønfjorden Bed show trough cross-bedding and occur in fining-up successions typical of the fill of a braided river (Fig. 10) (Kellogg, 1975; Dallmann, 1999). The conglomerate is clast-supported and the pebble- to cobble-size clasts are generally well rounded and spherical, showing little sign of imbrication. The conglomerates of the Grønfjorden Bed were therefore probably deposited as fluvial or alluvial-fan deposits, but are restricted to the western side of the basin.
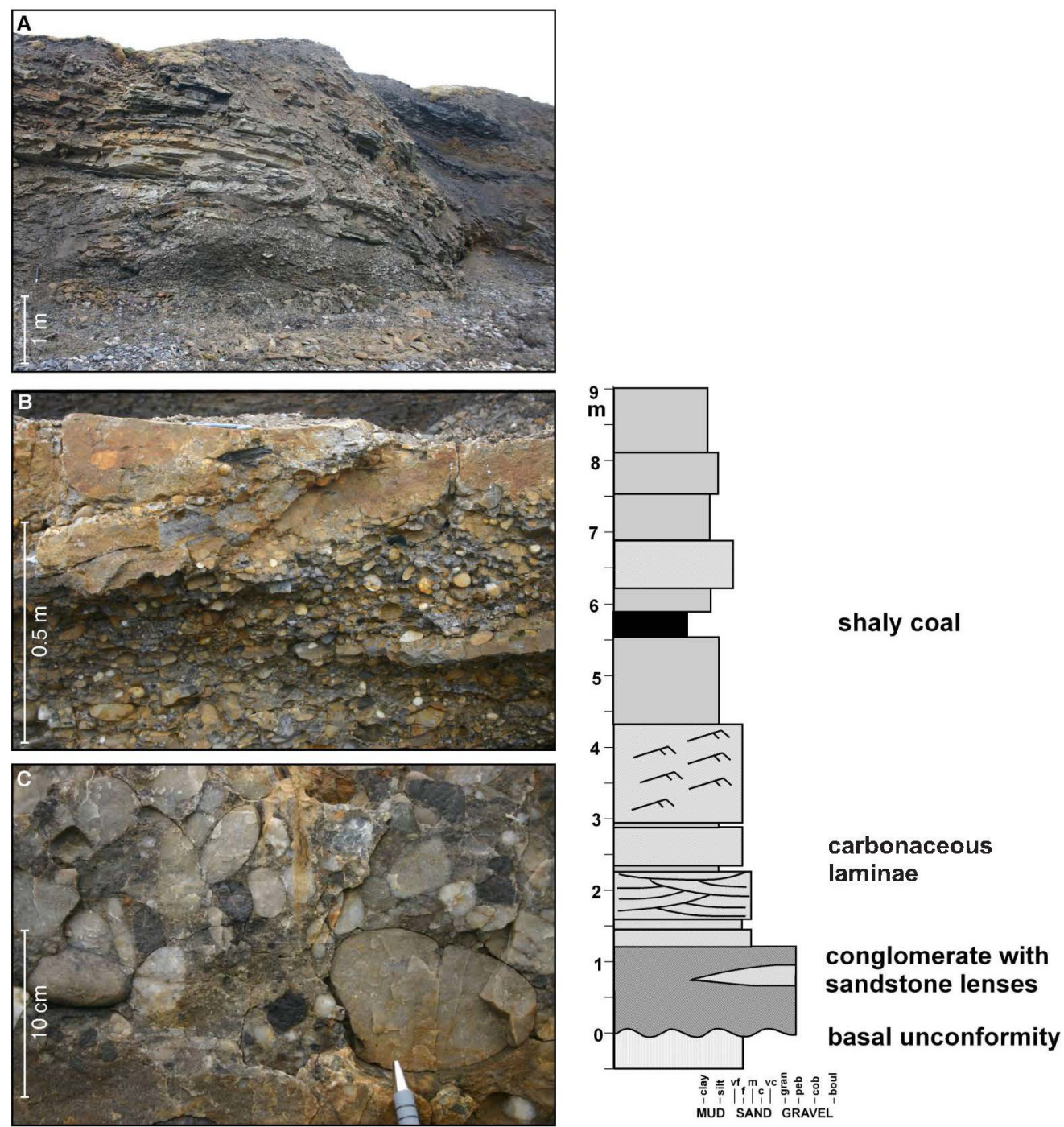

Figure 10 (A) Overview of the field site of the Grønfjorden Bed in Grønfjorden. (B) Cross-bedded conglomerate bed (subfacies Cgp1) in the Grønfjorden Bed of the Firkanten Fm in the northwestern part of the study area. The Firkanten Fm is interpreted as braided river deposits. Details of the well-cemented Grønfjorden Bed conglomerate. The log to the right is from Grønfjorden showing a fining-upwards fluvial section with a shaly coal bed near the top. 


\section{Interpretation of subfacies Cgp2}

The beds of subfacies Cgp2 occur associated with marine facies Sws, Sl and Sb (Fig. 9), and is clearly marine. The well-sorted beds of rounded clasts are interpreted as shoreline gravel that has been redeposited by agents working on the coast-like rip currents, longshore currents and wave action, to form beds of conglomerate (Hart \& Plint, 1995). Scours observed at the base of beds of facies Cgp are interpreted as wave- or tidal-induced erosive current features such as beach lags or storm deposits (Hart \& Plint, 1995). The clasts are likely to have been transported from a potential source area to the west (ergo the Grønfjorden Bed fluvial system) by marine processes such as currents induced by shoaling waves, storms and longshore currents, which can be major agents for moving gravel in the upper shoreface (Carr, 1971; Hart \& Plint, 1989, 1995).

\section{Interpretation of subfacies Cgm}

The mudclasts in Cgm (Fig. 8) may be either intraformational, generated from within the Firkanten $\mathrm{Fm}$, or extraformational and derived from underlying strata of the Carolinefjellet Fm. The clasts in the conglomerate at the base of the Todalen $\mathrm{Mb}$ are mainly derived from the underlying Carolinefjellet $\mathrm{Fm}$. Since the clasts are mostly angular, they were not transported very far but are expected to have come from a local high in the relief of the unconformity (Jochmann, 2004; Kostro, 2005). The scattered mudclasts in the rest of the Firkanten Fm probably originate from mudflat deposits where material deposited on tidal flats and around lagoons can become semi-lithified. These mudflat areas would have been eroded during storms and re-deposited as intraformational clasts. The angular clasts are not likely to have been transported very far, while the sub-rounded clasts could have been moved somewhat farther from the shoreline.

\section{Facies associations}

The facies described above have been grouped into four facies associations representing different depositional environments.

\section{FA1: Vegetated subaerial to marginal marine}

Facies association FA1 consists of the carbonaceous facies $\mathrm{K}$ and $\mathrm{Mk}$ that represent a vegetated continental to marginal marine sheltered environment, above the mean high-water level and flood-tide level and within the supralittoral zone (Fig. 11). Facies Ms and Sr occur associated with them but have a marine origin. This association suggests that the coal (Facies $\mathrm{K}$ ) was deposited in a near-shore environment such as a coastal plain close to a tidal flat or lagoon (Fig. 11). In the coal mines, these layers are found as extensive and flat continuous beds, and this is where the footprints of the Pantodonts Titanoides are found (Lüthje et al., 2010). This facies association occurs in a close association with marine facies suggesting that there was a broad low gradient coastal plain environment where even minor fluctuations in sea level would have affected large areas. The absence of fluvial facies in the central and eastern parts of the basin indicates that the coarser, fluvial deposits of the Grønfjorden Bed (facies Cgp1) were confined to the western side of the basin.

This interpretation of the continental facies as coastal plain deposits contrasts with the previous interpretation of the Todalen Mb as a delta-plain succession (Steel et al., 1981). Furthermore, McCabe (1984) suggested that active deltaic environments may not have a major potential for extensive peat 


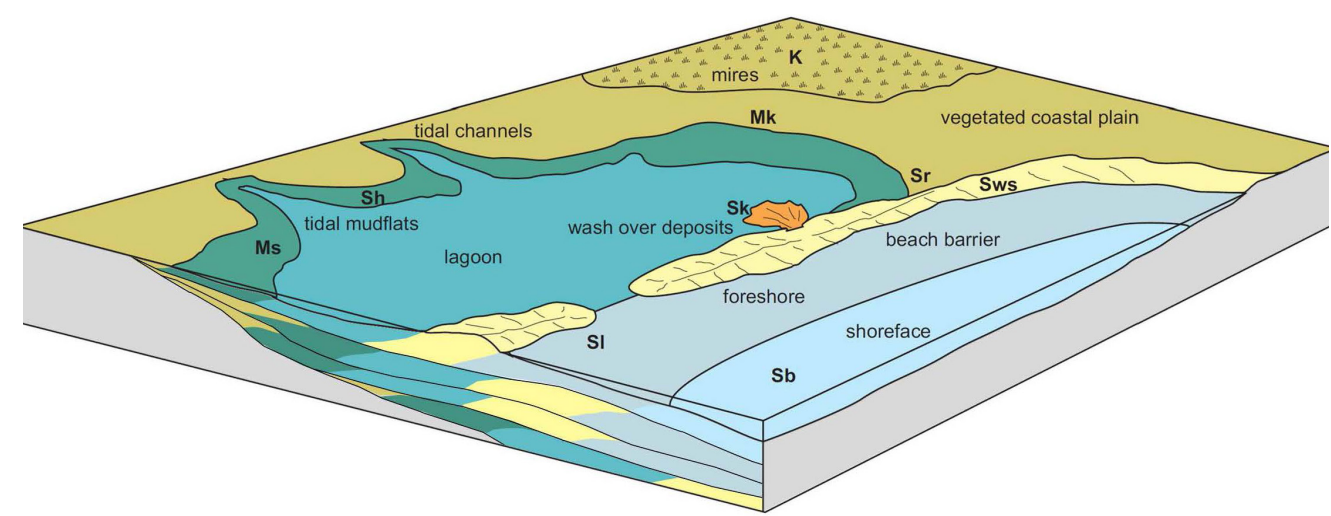

Figure 11 Conceptual diagram of the depositional environment and the distribution of facies of the Firkanten Fm based on detailed facies investigation of borehole and outcrop data. Facies codes are listed in Table 1, FA1 Vegetated subaerial to marginal marine, $\mathrm{K}$ coal and Mk carbonaceous mudstone; FA2 Back-barrier tidally influenced lagoon, Ms dark-grey muddy siltstone and Sh heterolithic sandstone and mudstone; FA3 Foreshore barrier bars, Sk organic-rich muddy sandstone, Sr rooted fine sandstone and Sws well-sorted sandstone; FA4 Shoreface, SI laminated sandstone and Sb bioturbated silty sandstone.

accumulations. In paralic settings the areas of peat accumulation can be extensive, only limited at the shoreline by the marine influence and inland by desiccation. Subsidence and eustatic sea-level changes determine the position of the shoreline and hence the extent of the coastal plain and coal deposit. The gradient of a shoreline will affect the extent of the coal accumulation (Diessel, 1992; Bohacs \& Suter, 1997). Low relief will give rise to potential broader peat mires as seen in the Todalen Fm.

\section{FA2: Back barrier tidally influenced lagoon}

Facies association FA2 comprises the heterolithic fine-grained strata of facies Ms and Sh interpreted as the deposits of tidally influenced environments. The Firkanten Fm is interpreted to have been deposited in a combined tidal and wave-influenced environment (Fig. 11) with the tidal flats and lagoonsacting as a buffer zonefor the vegetated areas protecting them from the marine influence. Thisfacies assemblage suggests a low-angle relief dissipative coast, with mixed tidal flat and lagoon facies. The coast is interpreted to have had a low angle by being dominated by fine material, and there are found the large extensive lagoons and peat mire environments.

The normal fair-weather waves would not have had much influence on the lagoons since they would have been sheltered by the barriers (Reinson, 1992), but storms could have had a great erosive effect on both tidal flats and lagoons. The beds of mudclast conglomerates (Cgm) found in the Todalen Mb are possibly generated from erosion of mudflats; tidal inlets and wash-over fans along the barrier bar would also have brought coarse material into the lagoons (Reinson, 1992).

The lack of evidence of well-developed meso/macrotidal influences (e.g., see Dalrymple, 1992; Reading \& Collinson, 1996) like large tidal channels and more tidal structures on the fine-grained sediments, indicate a microtidal setting for the Firkanten Fm. However, the tidal influence on the coastline can be significant even in a microtidal environment where a low gradient of the coastline means that even a small tidal range would involve movement of a large volume of water over a large area. The low sulphur content of the coal could be an indication that the tidal range was not high enough to affect the mire areas. 

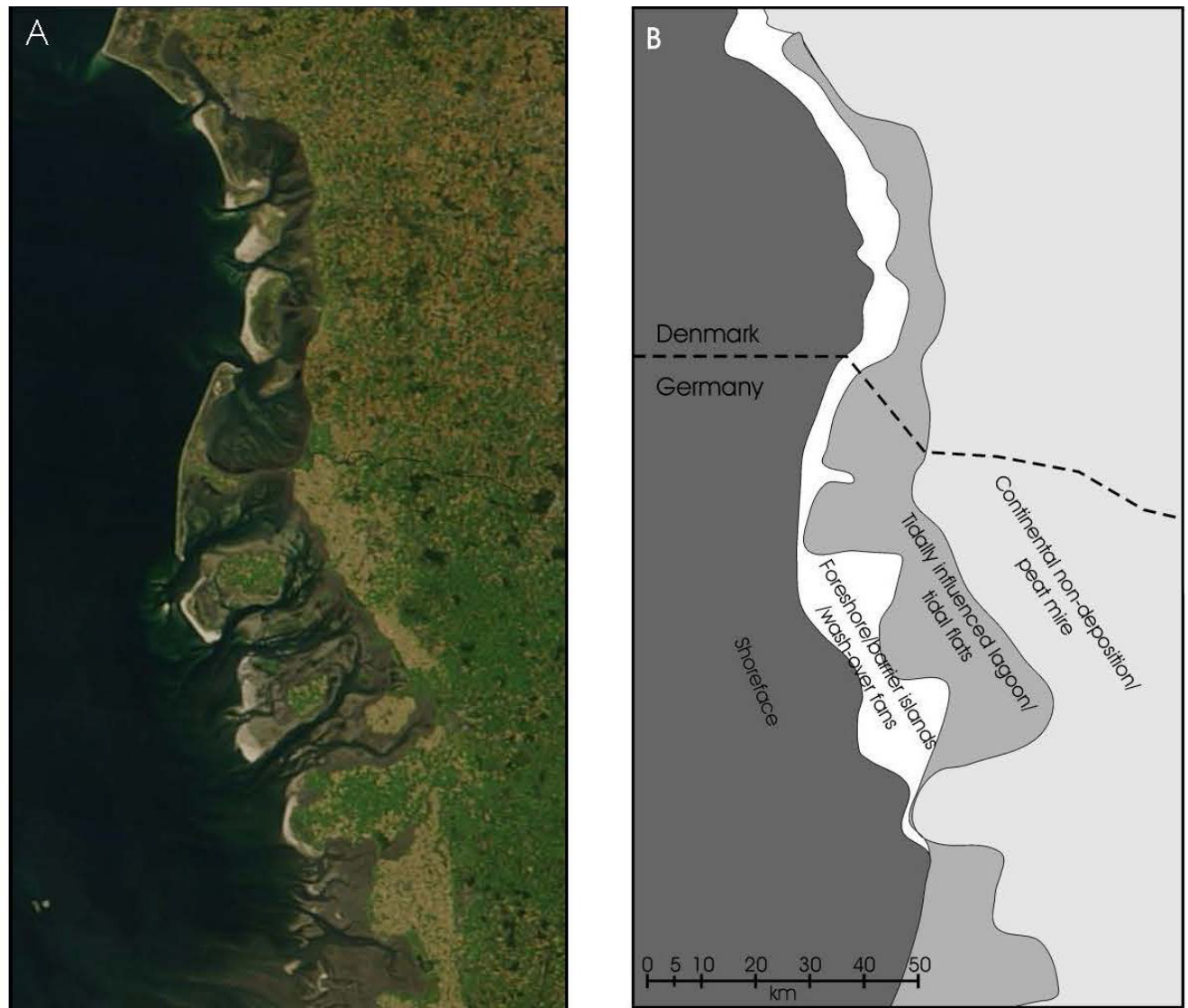

Figure 12 (A) Satellite image of the Danish Wadden Sea, a microtidal area which is a modern analogue for the depositional environment in the Firkanten Fm (MODIS image from NASA Visible Earth http://visibleearth.nasa.gov). (B) Description of the different environmental segments associated with the facies associations described from the Firkanten Fm. The maximum scale of each facies belt used in the correlation was derived from the modern environment; $5 \mathrm{~km}$ range perpendicular to shoreline for peat, swamp and barrier, respectively; $2 \mathrm{~km}$ for beach; $10 \mathrm{~km}$ for lagoon/ tidal-flat complex, upper shoreface, and lower shoreface, respectively (Johannessen et al., 2010).

A modern analogue for the fine-grained tidal deposits of the Todalen $\mathrm{Mb}$ could be the southeast coast of the North Sea, the Danish Wadden Sea (Fig. 12). This area shows a gradual decrease from mesotidal to microtidal range from the west (Holland $<3 \mathrm{~m}$ ) to the east (Denmark 1-0.5 m). The coast is overall transgressive, wave dominated with some storm influence and is situated in a temperate climate zone (Johannessen et al., 2010). The climate on Spitsbergen in the Paleocene has been interpreted to be warm-temperate with a high humidity equally distributed over the year (Golovneva, 2000; Cepek \& Kruttzsch, 2001), based on fossil plant material. There are, however, some large tidal channels on the southern North Sea coast despite the low tidal range, so the tidal range in the Todalen Mb may have been even lower.

Raised mires are normally very acidic, influencing the area outside of the mire and nearby deposits (McCabe, 1984). The absence of calcareous foraminifer taxa (Nagy, 2005) and carbonate shells in the Firkanten Fm could be due to dissolution caused by the acid from the mire waters. Calcareous nannofossils have been described only once from the Firkanten $\mathrm{Fm}$, a dissolution-resistant species indicating that dissolution of other forms had probably taken place (Cepek, 2001). High precipitation on the coastal plain pushes the saltwater interface seawards and leads to a larger area influenced by the acids from the mire, including penetration into underlying sediments. The restricted fauna found in the Todalen $\mathrm{Mb}$ (Nagy, 2005) could also be caused by the brackish environment in the lagoon created by freshwater run-off mixed with marine saltwater, creating an environment occupied only by a restricted fauna. 


\section{FA3: Foreshore barrier bars}

Facies Sk, Sr, Sws, Cgp2 and parts of Cgm represent a wave- and storm-influenced near-shore environment that includes all parts of the shoreline including beach (foreshore and backshore), the barrier bars and islands, back barrier sandy wash-over fans and tidal deltas as well as possibly the uppermost part of the shoreface (Fig. 11). Behind these barriers the lagoons and coastal plain environments of FA2 and FA1 developed, protected from the high-energy wave- and storm-influenced coastline. Root horizons show that the barriers were vegetated during fair weather and these vegetated barriers were probably eroded during storms and gave rise to the organic-rich wash-over deposits. The thin pebbly storm lags also indicate storm action on the coastline as material was reworked by wave action and transported by longshore currents (Hart \& Plint, 1995). Some of the thicker conglomerates in the Firkanten Fm are probably related to pebbly deposits on the beach. The tidal influences recognised in FA2 are not apparent in FA3, probably because the seaward side of the barriers were more strongly affected by storms and waves such that the tidal effects are not preserved.

\section{FA4: Shoreface}

The presence of hummocky-swaley cross-stratification and the relatively intense bioturbation within these facies $\mathrm{SI}$ and Sb suggest deposition in the lower shoreface, whereas the high proportion of sand beds indicate middle shoreface deposition. This facies association probably represents a middle to lower shoreface environment in both the Firkanten and Basilika formations (Fms).

In the Bay of Biscay, sediments derived from the northern side of the Pyrenees enter the basin by the river Gironde far to the north. In this modern analogue setting, the fine-grained sand is transported along shore by wave-induced currents and deposited in a narrow belt on the coast as well-sorted foreshore, beach and barrier bar deposits. There is no delta at the river mouth and all sediment is redistributed along shore. Offshore in the Bay of Biscay the sediments are generally muddy with a low sedimentation rate and glauconite production (pers. comm. T. Jacquin, 2007). Glauconite indicates low clastic sedimentation rates and is abundant in the Firkanten Formation. Transgressive systems typically have a higher tendency to retain sediments on the shore and less sediment is transported offshore creating a relatively sediment-starved shoreface. As a consequence of this, the muddy lower shoreface sediments in the Firkanten Fm were probably deposited in shallower water than is indicated by the grain size and bioturbation.

\section{A coastal depositional environment for the Firkanten Fm}

The sediment input and the energy regime (waves, storms and tides) control coastal environments that can be classified by the dominant processes (Boyd et al., 1992). The three end members - wave, tidal and fluvial - interact to shape the coastline, whilst the sea-level change and rate of sediment supply will give rise to regressive/progradational or transgressive/retrograding coastlines with different character (Boyd et al., 1992). The facies of the Firkanten and Basilika Fms indicate a transgressive environment and there is no evidence for valley incision or sea-level fall in the succession. Transgression and low sedimentation rates in a wave-dominated setting typically result in a barrier bar and lagoon system (Boyd et al., 1992), as interpreted in the Firkanten Fm. Some tidal influence and fluvial input may be present, but is of minor importance for the coastal system. Tidal-dominated shorelines do not have 
well-developed barriers as the tides help to maintain a low relief of the coastline, whilst fluvialdominated coastlines are characterised by deltas and show stronger evidence for progradation.

The Todalen $\mathrm{Mb}$ is characterised by muddy fine-grained sediments with a high organic content deposited in a marginal marine environment. The foreshore and shoreface deposits of the Endalen $\mathrm{Mb}$ consist predominantly of well-sorted sand. At a coast with low fluvial sediment input and a general rising sea level, the fine sediment will tend to be trapped onshore in the back barrier system where there will be accumulation space available. In transgressive systems, less sediment is transported and deposited farther out into the basin (Johnson \& Baldwin, 1996) as the sediment is trapped in nearcoastal systems such as beach barrier systems (Fig. 9). However, at the foreshore and shoreface the sediments are reworked and winnowed by waves and storms and therefore no mud is found, only well-sorted sand. During normal wave conditions on the shoreface, sands build up the sandy barrier islands (Hart \& Plint, 1995). Wash-over fans are produced and are likely to be preserved in the stratigraphic record (Reinson, 1992), and are found in the Firkanten Fm (facies Sk). Conglomeratic beds are mainly associated with marine facies and were deposited as gravelly lags in beach, foreshore and shoreface settings. There is no indication of incision that could indicate that any of the marginal marine sediments could represent estuary deposits and the finer-grained sediments are interpreted as the deposits of a tidally influenced lagoon or combined lagoon/tidal-flat area (Fig. 11).

\section{Correlation in the Firkanten Fm}

An implicit assumption in previous studies has been that the basal unconformity can be used as a datum. Although in places the surface seems to have little or no relief - for example, in the mountainsides around Adventdalen the unconformity surface appears to be an almost horizontal, flat surface (Fig. 3) - borehole data reveals that there can be as much as $20 \mathrm{~m}$ vertical difference in elevation of the surface between locations a few hundred metres apart. In an area of low-relief coastal plain and foreshore to shoreface deposition, topography of just a few metres could have a strong control on the distribution of facies. Furthermore, the lateral changes in these environments over distances of kilometres means that lithostratigraphic units would be diachronous and would not provide a satisfactory basis for anything other than local correlation. Biostratigraphic correlation using calcareous nannofossils, calcareous microfossils or palynomorphs has not been possible within the Firkanten Fm due to dissolution of all carbonate and intense silica cementation that has made it extremely difficult to extract palynological material for dating (pers. comm. M. E. Collinson, 2006).

\section{Widths of facies belts and modern environments}

Sedimentation in marginal marine settings is sensitive to minor relative sea-level changes and hence correlation on the basis of the recognition of base level changes could be used for the Firkanten Fm. The depositional model (Fig. 11) was used as the basis for determining the facies that would be correlated, simply assuming that facies associations FA1, FA2, FA3 and FA4 would occur as lateral equivalents in that order at any point in time. Consideration was also given to the likely widths perpendicular to the paleo-coastline of the subcrop of each of these facies associations by comparison with analogous modern environments. Two examples of modern coastlines were selected, each with low relief, a wave-dominated micro- to mesotidal setting, a comparable humid climatic setting with peat formation and a clastic shoreline: the Danish Wadden Sea (Fig. 12) and the French coast of the Bay of Biscay, previously described. The Danish Wadden Sea is described by Johannessen et al. (2010) as a flat, low-relief, lagoonal protected area with peat formation, with a similar depositional setting as seen in the Firkanten Fm. The Wadden Sea has today a tidal range of only 1-1.5 m whereas there are still 
relatively deep tidal channels $(6 \mathrm{~m})$. This type of channel range is not found anywhere in the Firkanten Fm and could indicate that the tidal channels did not have time to develop or the tidal range was even lower. The measured widths of the different elements in these modern examples (coastal plain, lagoon, beach barrier and so on) were used to help constrain the likely widths of each of the facies associations in any isochronous unit: for example, correlations did not allow the foreshore/ beach barrier facies association to extend more than a few kilometres perpendicular to the shoreline (Johannessen et al., 2010). The maximum scale-bar used was a $5 \mathrm{~km}$ range perpendicular to shoreline for peat, swamp, barrier, respectively; $2 \mathrm{~km}$ for beach; $10 \mathrm{~km}$ for lagoon/tidal-flat complex, upper shoreface, and lower shoreface, respectively, as also found by Johannessen et al. (2010).

\section{Coal seam character}

The characteristics of the coal seams have provided an additional tool for creating a correlation framework. The coal seams are all located in the Todalen Mb and have been informally named by the local Norwegian coal company (SNSK) with five seams recognised: from bottom to top these are the Svea, Todalen, Longyear, Svarteper and Askeladden seams. This naming of the coal seams should not be regarded as a definition of five discrete coal layers that can be correlated. It is rather a generalisation of a group of coal seams that have the same apparent characteristics and are related in time (Fig. 2). The different characteristics of the coal seams are reflecting the climate at the time of deposition. Coal seams should normally only be correlated over distances of 1-2 km.

The two main commercial seams are the Svea and Longyear seams. Svea is exploited at the Svea Nord mine, which has a relatively high inertinite content (c. $40 \%)$ and a low volatile content $(<30 \%)$ whilst the Longyear seam, mined in Gruve 7 at Longyearbyen, typically contains a very high proportion of vitrinite (c. 90\%) and a high volatile content (>30\%) (Orheim et al., 2007). Between the Svea and Longyear seams the poorly developed Todalen seam shows intermediate values of volatiles. The two uppermost coal seams, the Svarteper and Askeladden seams, are only found in the area north of Adventdalen, and have higher ash and sulphur contents than the lower seams. The development of the coal deposits is probably reflecting the development of the entire depositional environment.

The seams can therefore be used as marker horizons because it is possible to distinguish between some of them in core on the basis of their relative maceral and volatile contents. Information from the analysis of coals encountered in cores, provided by SNSK, could therefore be used to identify which of the seam group the coal interval was likely to represent out of the five. The relative time of deposition could thereby be established (Fig. 2).

\section{Correlation methodology}

Correlation of coal intervals between cores and consideration of the likely lateral extent of individual facies units provided a basis for setting up a sequence-stratigraphicframeworkfor the succession. Shallowing-up successions were identified, with FA4 representing the deepest water deposits and FA1 the shallowest, each of which was bounded by a change from relatively shallow to relatively deep facies. These successions are here considered to be parasequences (PS) bounded by minor marine flooding surfaces using the sequence-stratigraphic terminology of Van Wagoner et al. (1990) and Kamola \& Van Wagoner (1995). The parasequences are combined into larger parasequence sets (PSS) separated by major surfaces of marine flooding. Construction of the correlation panels (Figs. 13, 14 \& 15) was an iterative process, with multiple attempts at correlation between all the boreholes before solutions were found that (a) honoured the coal seam character data (b) resulted in strike-perpendicular facies belts that were consistent with the modern analogues chosen and (c) indicated paleogeographic distribution of sub-environments (see below) that were relatively simple. 


\section{Parasequences}

The lower part of the Firkanten $\mathrm{Fm}$, the Todalen $\mathrm{Mb}$, comprises continental and marginal marine parasequences deposited in a tidally influenced semi-enclosed lagoon. The prograding successions that form parasequences in this environment show a transition from the tidal-flat, heterolithic, muddy sandstone (Facies Sh) through tidal mudflat deposits (Facies Mk and Ms) to marginal marine, swamp,

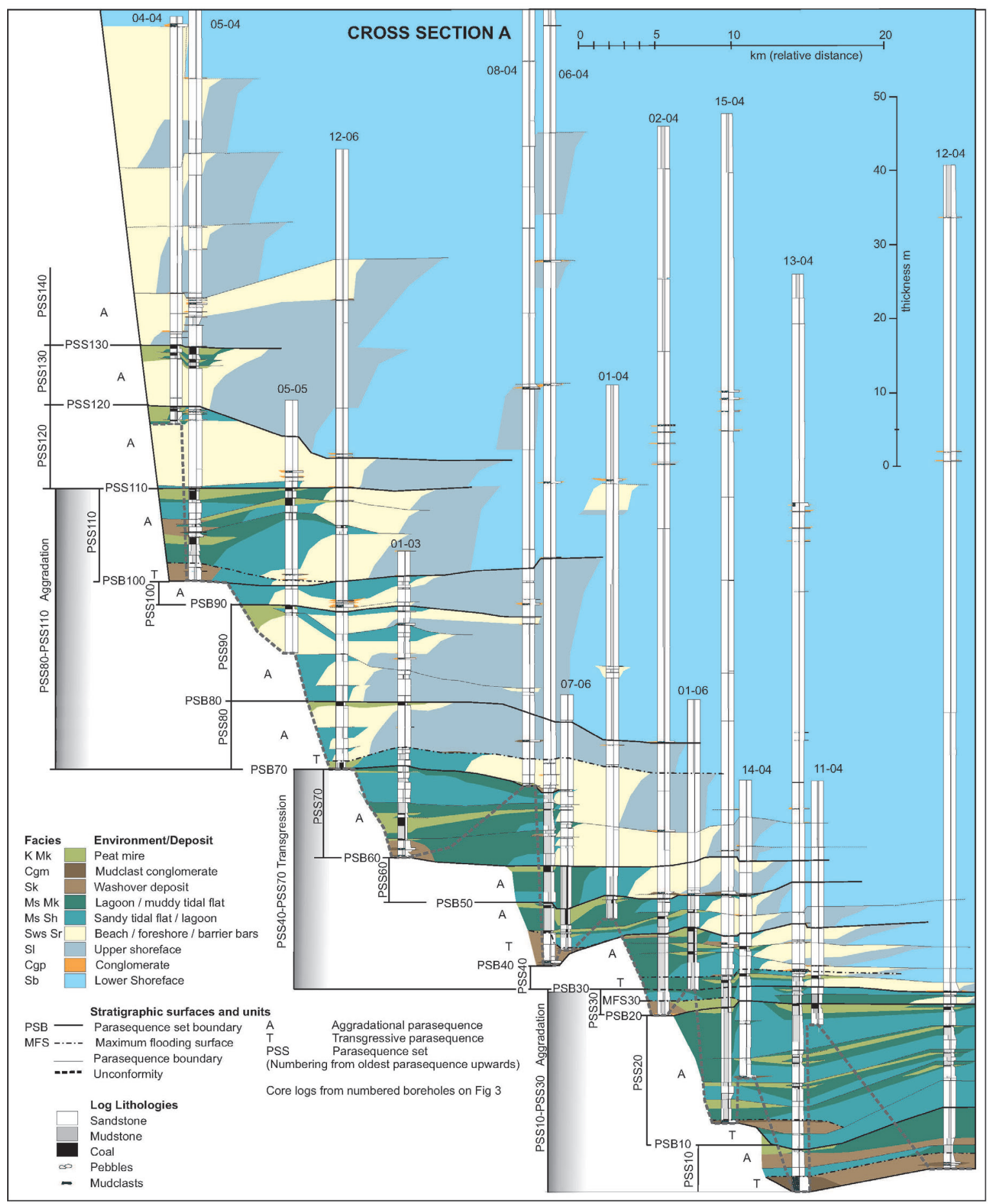

Figure 13 Correlation panel of the eastern side of the basin from south of Svea to Reindalen to Longyearbyen, based on borehole data located in Fig. 4B. The coal seams have been used for helping the correlation as explained further in the text. The oldest coal seams have a composition representing the Svea coal seam group; the middle Longyear and the youngest are more similar to Svarteper and Askeladden. However, since individual coal seams cannot be correlated over large distances there are no direct coal seam identifications. 
carbonaceous mudstone (Facies Mk) overlain by peat (Facies K coal) (Fig. 16). The coastal successions, show progradation from well-sorted sandstone of the barriers and foreshore (Facies Sr, Sk and Sws) to heterolithic tidal and lagoon deposits (Facies Sh and Ms) and carbonaceous mudstone and coal (Facies $\mathrm{K}$ and Mk) (Fig. 16). The upper part of the Firkanten Fm, the Endalen Mb, represents fully marine conditions and parasequences show transitions from bioturbated sandstone (Facies Sb), to laminated sandstone (Facies SI), and well-sorted sandstone (Facies Sk, Sr and Sws) representing the transition from the muddy bioturbated lower shoreface, to the storm-dominated, hummocky cross-stratified shoreface and the wave-dominated foreshore, respectively (Fig. 16).

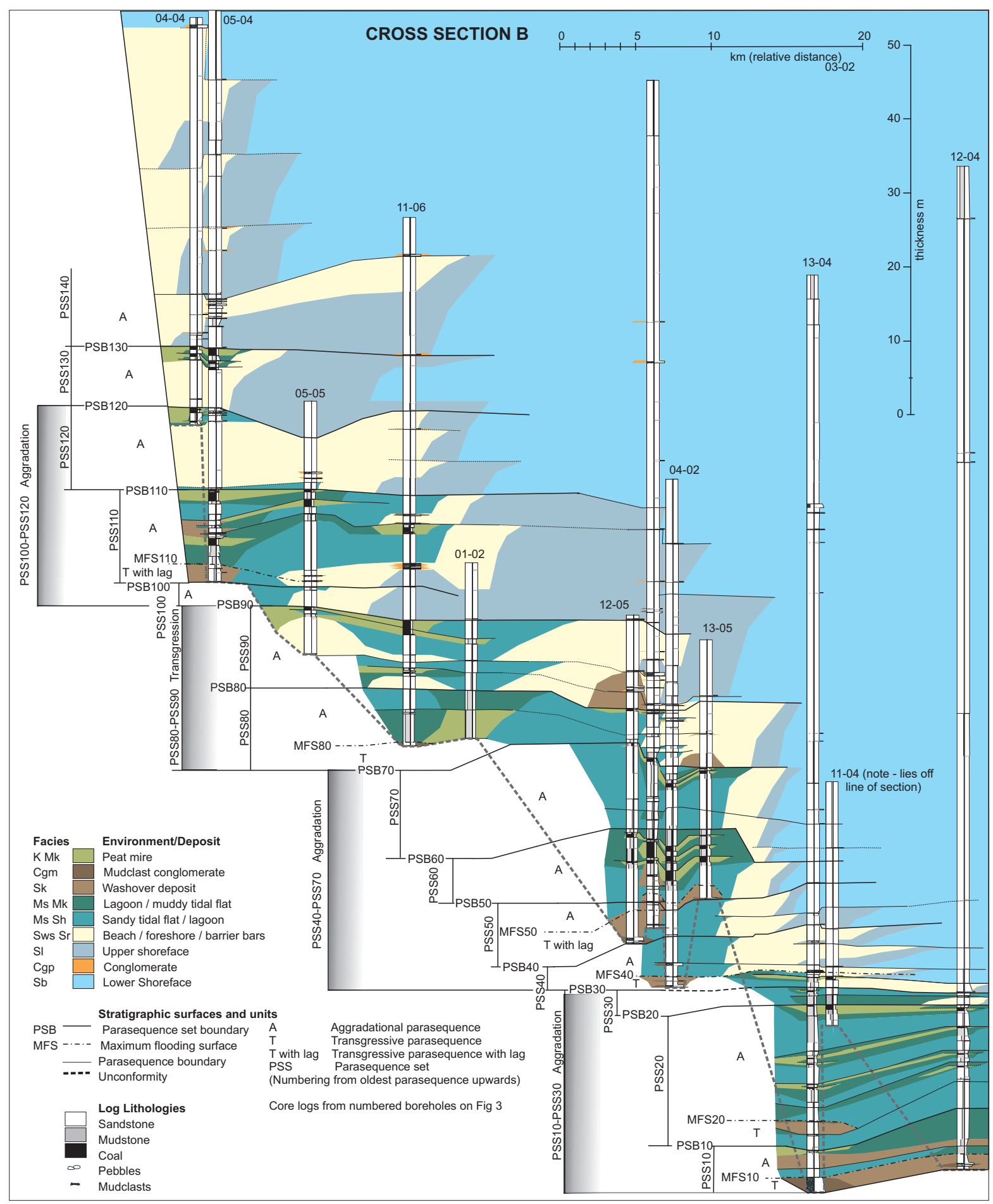

Figure 14 Correlation panel of the eastern side of basin from south of Svea to Ispallen to Longyearbyen, based on borehole data located in Fig. $4 B$. 


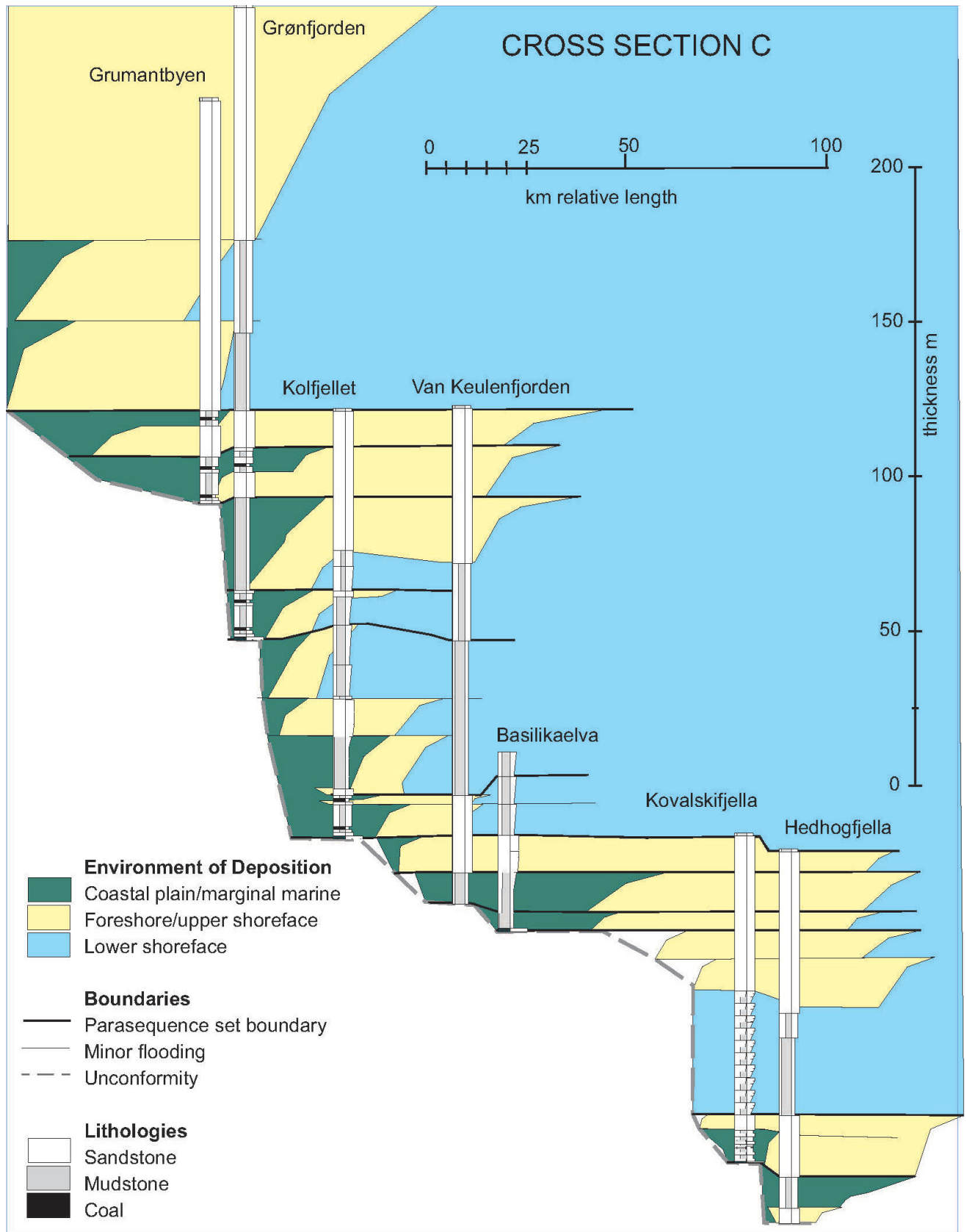

Figure 15 Correlation panel of the western side of the basin from Hedgehogfjella to Grønfjorden and across the basin to Carolinefjellet, based on locations in Fig. 4A described by other authors: Hedgehogfjella, van Keulenfjorden, Grønfjorden and Grumantbyen (Kellogg, 1975), Kovalskifjella (Nagy, 1966), Basilikaelva (Nagy, 2005) and Kolfjellet (Kellogg, 1975; Nagy, 2005).

The parasequences are bounded by minor flooding surfaces that can be traced over distances of more than $20 \mathrm{~km}$. The most continental parts show facies transitions over the flooding surface from carbonaceous mudstone or coal (FA1) to heterolithic muddy sandstone or mudstone of tidal flats or lagoons (FA2). The marginal marine setting is characterised by parasequence boundaries that show changes from back-barrier, poorly sorted, fine-grained material with high organic content (FA2) to well-sorted marine sandstone of the foreshore and upper shoreface (FA3). The wash-over fan deposits (Facies Sk and Cgm) are sometimes preserved representing the flooding events. In the marine sections of the Endalen $\mathrm{Mb}$ and the Basilika $\mathrm{Fm}$ the parasequence boundaries show a transition from the well-sorted foreshore (FA3) to the bioturbated shoreface (FA4). In places the flooding surface 


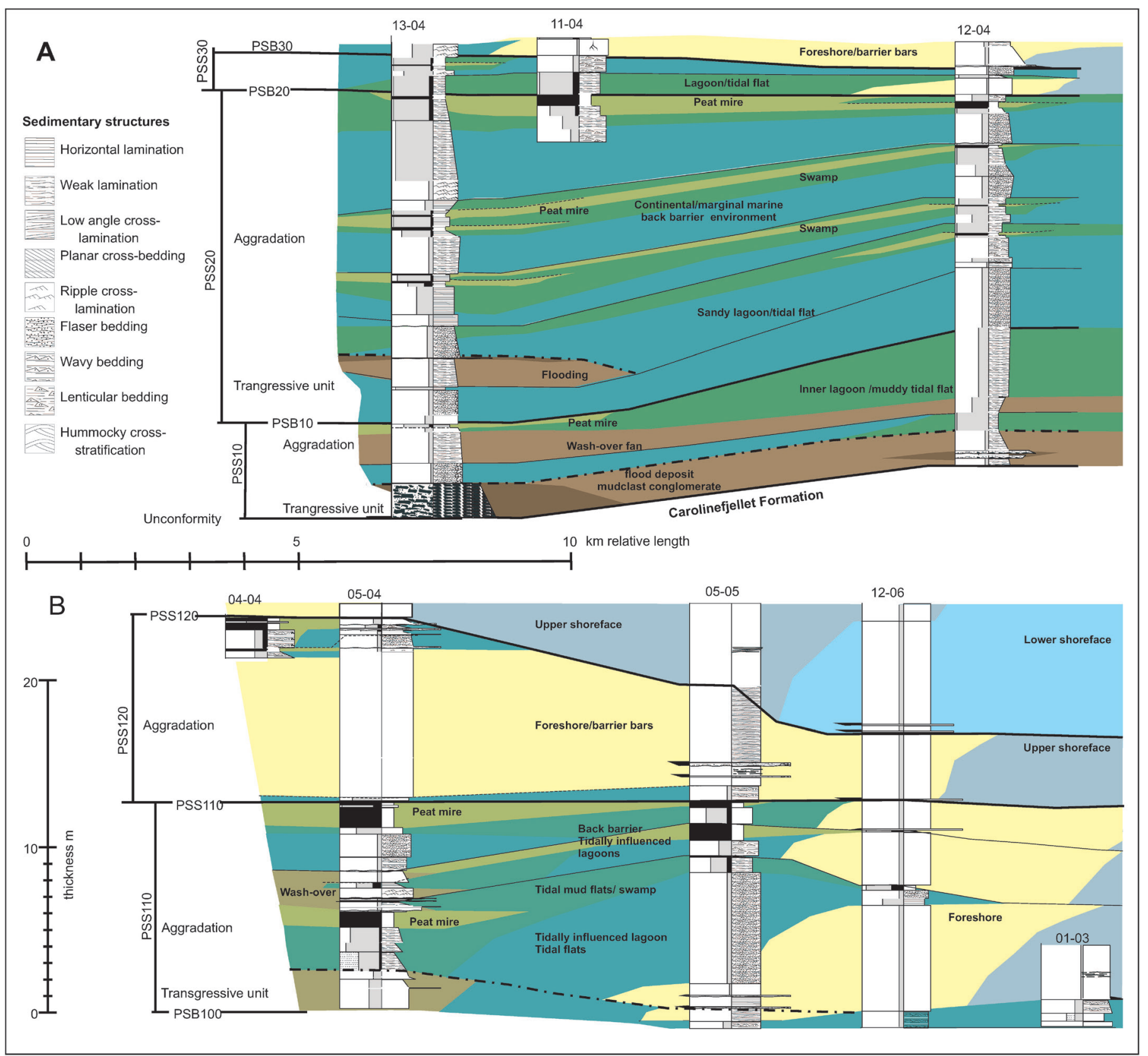

Figure 16 Details of log correlation from the cross-section in Fig. 13. (A) Coastal marginal marine setting of a thick aggrading succession with coal typical for the lower part of the Todalen Mb in the Svea area, representing the Svea coal seam. (B) Detailed section showing parasequence progradation and the boundary flooding surfaces in a marginal marine setting of lagoon overlain by peat. The parasequences are stacked in an aggrading pattern and the parasequence set boundary is a major flooding surface with a shift from lagoon to foreshore/shoreface settings.

is marked by thin conglomeratic beds containing mostly rounded pebbles (Facies Cgp2). The extent of the flooding in each case was limited to the position of the shoreline established by the previous flooding event: successive parasequences within a set therefore generally show an aggradational stacking pattern.

\section{Parasequence Sets}

The parasequence sets are bounded by major flooding surfaces and consist of a dominant aggradational succession with a thin transgressive unit at the base in places. The record of the 
transgression is mainly preserved as wash-over fans or deposits resulting from reworking (Facies Sk and Cgm), although there are some cases (e.g., PSS40 and PSS80, Figs. 13 \&14) where a thicker continental to marine succession is present. The major flooding surfaces involve marine flooding of previously non-depositional areas and are also marked by a facies change from continental or mudflat/ lagoon facies (FA1 or FA2) to shallow-marine barrier island/foreshore and marine shoreface deposits (FA3 and FA4). The shift in the coastline towards the northwest at each event was typically 10 to $15 \mathrm{~km}$. Patterns within the parasequence sets are typically aggradational, with successive parasequences in places building up vertical successions of the same facies associations. These thick packages of aggradational deposits indicate that the relative sea-level change and sediment supply were approximately in equilibrium for long periods, punctuated by events (major flooding surfaces) when relative sea-level rise exceeded sediment supply.

\section{Erosion Surfaces}

There is a major erosion surface at the base of the Firkanten Fm where the Cenozoic succession lies unconformably on the Carolinefjellet Fm of Albian/Aptian age, a hiatus of approximately $35 \mathrm{Ma}$ (Fig. 2) (Dallmann, 1999). The correlation panels (Figs. 13, 14 \& 15) reveal a gentle sloping relief on this surface as the transgressive succession onlaps towards the north. Relief on this surface resulted in the deposition of localised conglomerate beds (Cgm derived from erosion of the Carolinefjellet $\mathrm{Fm}$ ) between $0.1 \mathrm{~m}$ and $2 \mathrm{~m}$ thick, although this relief was localised (Steel \& Dalland, 1978; Jochmann, 2004; Nagy, 2005) and the topography was subsequently filled in by continental and marginal marine facies.

The major marine flooding surfaces that separate parasequence sets are commonly associated with thin, laterally extensive pebbly conglomerate (Facies Cgp2) made up of rounded, sorted pebbles and they are overlain by marine facies of FA3. Since the conglomerate layers are associated with the marine flooding, they could represent transgressive lags deposited by storms on the marine erosion surface (ravinement), which was created by wave action during transgression (Siggerud \& Steel, 1999; Catuneanu, 2002). Within the study area there was no evidence of any erosion surfaces that cut down through underlying strata within the Firkanten Fm.

\section{Systems tract and sequence analysis}

All of the parasequence sets within the succession display either aggradational or retrogradational patterns of parasequences within them. Furthermore, the overall stacking pattern of the parasequence sets is retrogradational: there is no evidence for a relative sea-level fall and none of the parasequence sets shows a progradational stacking pattern. The entire succession could therefore be considered to have formed in a single transgressive systems tract composed of multiple parasequence sets, with the only sequence boundary occurring at the basal unconformity with the Lower Cretaceous Carolinefjellet Fm. Overall accommodation was created by subsidence of the Central Tertiary Basin, with the long-term pattern showing that accommodation was being created at a higher rate than the supply of sedimentation. Variations in the balance between accommodation and sediment supply are evident on several scales and individual parasequences were formed by minor flooding episodes creating accommodation that was subsequently filled by nearshore to paralic facies. The vertical interval between minor flooding surfaces is generally between $1.5 \mathrm{~m}$ and $5 \mathrm{~m}$, indicating relative sea-level rises of similar magnitudes, but larger if burial compaction is taken into account. At a larger scale, parasequence sets are typically 3 to $17 \mathrm{~m}$ thick and they are separated by major flooding surfaces that mark landward shifts in the facies belts of the order of 10 to $15 \mathrm{~km}$. 

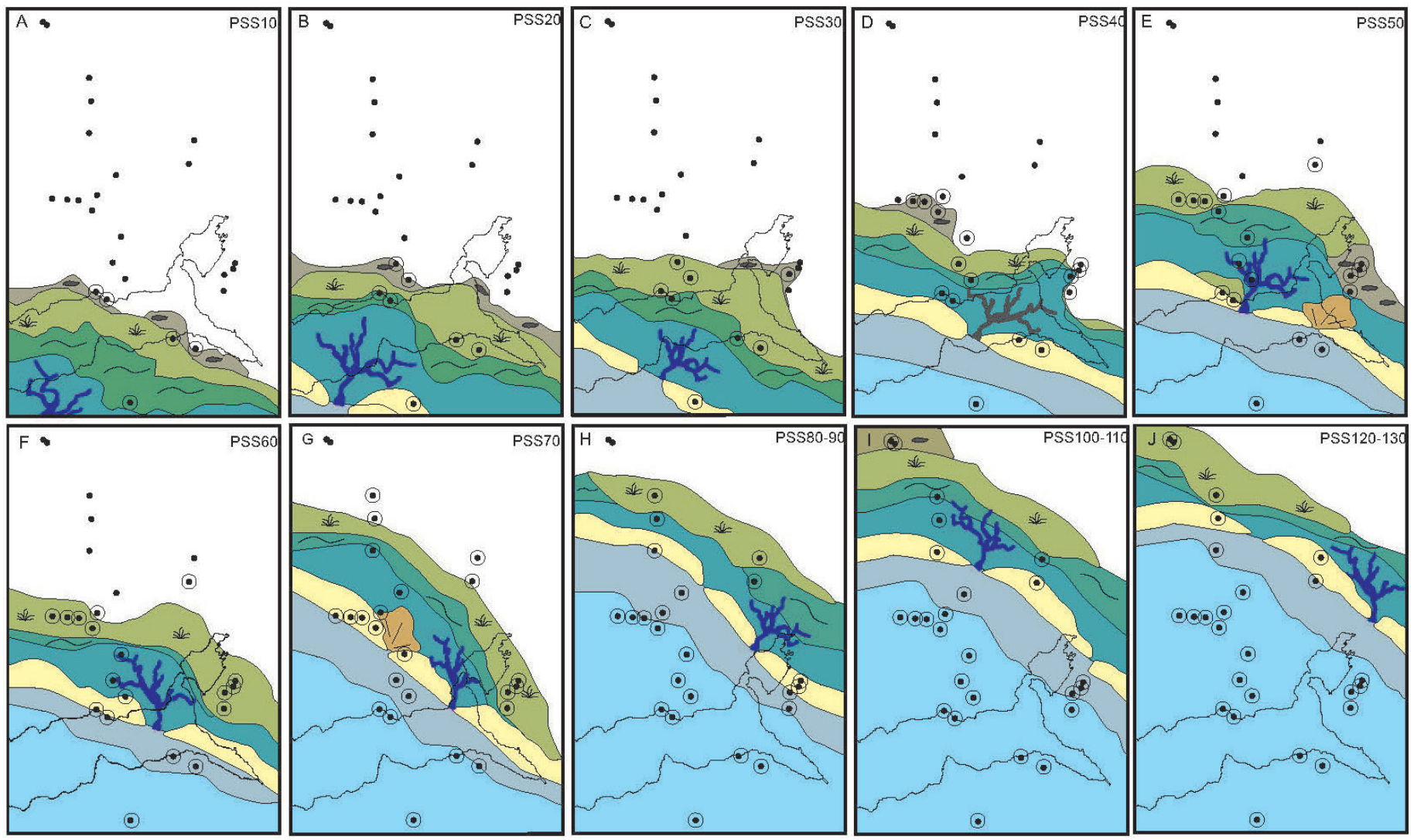

Weathered/mudclasts
Vegetated/Peat formation

Swamp/idal mud flat Wash-over fan
Lagoon/Tidal flat

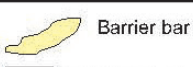

$\square$ Lower shoreface

- Borehole location

- Borehole data used in map

Figure 17 Detailed paleogeographic reconstruction from the parasequence sets PSS10 to PSS130 from Figs 13 and 14: (A) PSS10; (B) PSS20; (C) PSS30; (D) PSS40; (E) PSS5O; (F) PSS60; (G) PSS70; (H) PSS80-90; (I) PSS100-110; (J) PSS120-130.

\section{Paleogeographic reconstructions}

The paleogeographic maps (Fig. 17) were constructed from the correlation panels (Figs. 13 \& 14) and the individual core data points. All the cores used in the correlation penetrate the unconformity with the Carolinefjellet Fm. In cross-section, the local topography stands out clearly (Figs. 13 \& 14) and on the paleogeographic reconstruction the highs are represented as areas of non-deposition. These highs shed eroded material to areas nearby, which are often characterised by mudclast conglomerate beds. For locations, see Fig. 4.

\section{Parasequence sets PSS10-PSS30 - Aggradation}

Parasequence sets PSS10 to PSS30 represent the initial flooding of the area south of Svea with the establishment of a vegetated coastal plain (FA1) with a tidal-influenced lagoon (FA2) protected by sandy barrier bars and shoreface (FA3) to the south.

PSS10 (Fig. 17A) - Deposition near Svea was marginal marine with only minor peat accumulation, correlated to foreshore and shoreface deposits of the Endalen Mb farther south. The initial flooding left a thick transgressive unit of weathered material (Facies Sk organic-rich sandstone and Cgm mudclast conglomerate) on top of the unconformity (Fig. 13). 
PSS20 (Fig. 17B) - Again a transgression left a thin layer of mudclast conglomerate and poorly sorted sandstone at the base (Fig. 13). The coastline retreated towards the northeast with the main foreshore and shoreface sandstone deposits lying to the south.

PSS30 (Fig. 17C) - The foreshore and beach retreated $8 \mathrm{~km}$ northeast whereas the lagoon and tidal-flat area of the back barrier mainly remained in place. The marginal marine area expanded inland and there was a limited amount of peat accumulation.

\section{Parasequence sets PSS40-PSS70 - Retrogradation}

Parasequence sets PSS40 to PSS70 show a general retrogradational trend although there are thick aggradational sections. The largest shifts in environments of deposition in this part of the basin occurred in this period.

PSS40 (Fig. 17D) - A major shift in the coastline of 9 km occurred and a tidally influenced lagoon became established in the Ispallen area, where local topography on the underlying Carolinefjellet Fm provided a thick mudclast conglomerate (facies Cgm). The area west and northwest of Svea was characterised by muddy lagoon and tidal-flat facies with swamps.

PSS50 (Fig. 17E) - There was a small shift in the coastline at this stage, but the area of deposition of mudclast conglomerate expanded in the Ispallen area, blanketing the local topography. In the Svea area, a mire was established and remained in place for long enough to accumulate the peat deposits which became the Svea coal seam.

PSS60 (Fig. 17F) - In the area around Ispallen, a peat mire complex was established resulting in a thick coal deposit. South of Ispallen the foreshore and shoreface only shifted small distances whereas the area west of Svea was influenced by the marine transgression moving the coastline several kilometres (Fig. 14). This apparent rotation of the coastline may have been either the raised mire complex around Ispallen acting as a barrier to coastal flooding (cf., McCabe \& Shanley, 1992; Kamola \& Van Wagoner, 1995) or there was some differential tectonic subsidence at this eastern edge of the basin.

PSS70 (Fig. 17G) - Further rotation of the coastline occurred with transgression across the Reindalen area northwest of Svea. To the east the area around Ispallen and Svea continued to be an area of swamp formation.

\section{Parasequence sets PSS80-PSS110 - Aggradation}

Parasequences PSS80 to PSS110 are characterised by an aggradational trend and there is a change in the character of the coastal environment, with the shoreface area becoming wider whilst coastal plain mires became less widespread and created thinner accumulations of peat.

PSS80-PSS90 (Fig. 17H) - During this period the mire areas of Svea and Ispallen were flooded as the coastline shifted north establishing foreshore and barrier systems in these areas. To the northwest the transgression reached the area near Longyearbyen.

PSS100-PSS110 (Figs. 17I) - The coastline fluctuated during these periods, but without any significant transgression taking place. Foreshore sedimentation was characterised by coarser sedimentation than at previous stages, with a pebbly conglomerate being deposited. In the Longyearbyen area, a backbarrier, tidally influenced lagoon was established in PSS110 and behind this, mires formed accumulating the peat that now forms the Longyear coal seam exploited in the Gruve 7 mine. The main deposition of the Longyear coal seam began in PSS110. 


\section{Parasequence sets PSS120 and above}

PSS120-PSS130 (Fig. 17J) - In contrast to the lower parts of the succession, the areas of tidal-flat and lagoonal deposition became much narrower and mire development was much closer to the beach barrier. Observations from north of Adventdalen indicate a later reestablishment of a wide coastal plain (Wilhelmsson, 1999) where the peats of the Svarteper and Askeladden coal seams were deposited.

Lately, even farther north of the Isfjorden, a recently reinvestigated area reveals an even younger section of the Firkanten Fm (Jochmann et al., 2019). This confirms the general continued transgression towards the north of the basin.

\section{Controls of sedimentation}

The aggradational and retrogradational parasequence patterns identified could be formed under conditions of a steady rate of creation of accommodation with cyclical variations in sediment supply. Most of the sediment is sourced from the marine environment, supplied by tidal currents, waves, storms and longshore drift along the coastline. However, there is no obvious mechanism for the cyclical control on sediment supply in a shallow-marine environment, particularly the periods of non-sedimentation that would be implied by the major flooding surfaces, so sediment supply variations are not considered to be major factor in generating the observed stratal patterns. A combination of tectonic and eustatic controls on relative sea level in the Central Tertiary basin are therefore considered to be responsible for the stratigraphic patterns documented in the Firkanten Fm.

\section{Tectonic controls on sedimentation}

The origin of the basin has been variously described as having formed in an extensional or transtensional setting (Kellogg, 1975; Steel et al., 1981; Steel and Worsley, 1984; Steel et al., 1985) with more recent work focusing on a flexural origin (Bruhn \& Steel, 2003; Dørr et al., 2013) in a compressional or transpressional setting (Müller \& Spielhagen, 1990; Braathen et al., 1999a, b). The West Spitsbergen Fold and Thrust Belt (Fig. 1) is a zone of Cenozoic shortening and the broad asymmetric syncline form of the basin (Kellogg, 1975; Winsnes, 1988; Dörr et al., 2013) indicates a compressional or transpressional phase in the basin history (Maher et al., 1995). The foreland flexure origin for the basin favoured by Bruhn \& Steel (2003) requires the onset of shortening in the West Spitsbergen Fold Belt and loading of the crust to the east to have occurred prior to the Late Paleocene. On the basis of evidence from northern Greenland, Manby \& Lyberis (2000) argue that deformation in the West Spitsbergen Fold Belt occurred in the Late Cretaceous to Paleocene. However, this timing is disputed by other authors who contend that the main episode of compression and uplift occurred in late Paleocene and Eocene times (Maher et al., 1995; Braathen et al., 1999a, 1999b). Thermochronological studies using ${ }^{40} \mathrm{Ar}-{ }^{39} \mathrm{Ar}$ age spectra and apatite fission-track length models (Blythe \& Kleinspehn, 1998) indicate that uplift may have commenced in the Late Cretaceous (Manby \& Lyberis, 2000), but the data also show that there was significant uplift in the Eocene (Maher, 2001). Deformation of Eocene strata in the Central Tertiary Basin confirms that shortening in the West Spitsbergen Fold Belt continued into the Eocene (Braathen et al., 1999a, b).

Thermochronological studies (Dörr et al., 2012) indicate that uplift of Svalbard during Mesozoic and Cenozoic time was spatially variable, with the greatest amount occurring in the northern part of the archipelago. The sediment flux into the Central Tertiary Basin on Spitsbergen in the Paleocene was therefore predominantly from the north (Dörr et al., 2012). The east-west orientation of the coastline in the basin is therefore consistent with the regional uplift and sediment supply trends. Schlegel et 
al. (2013) suggested that the mineralogical change in the sediments in the Central Tertiary Basin was mostly caused by climatic changes, rather than a change of provenance. There are some indications in the petrography of a gradual lowering of the relief of the source area or that it developed from a proximal to a distal setting.

Basins formed by flexural loading are generally considered to be either retro-arc basins related to subduction at an active continental margin or are peripheral foreland basins formed adjacent to an orogenic belt (Allen \& Allen, 2005).The absence of contemporary magmatism precludes a retroarc origin, but the history of sedimentation is also atypical of peripheral basins, where loading of thinned foreland crust typically results in a basin that is deep in its initial stages (Watts, 1992; Allen \& Allen, 2005). The shallowing-up signature of the fill in a peripheral foreland basin (Einsele, 2000) is not seen as the initial sedimentation in the Firkanten Fm was at sea level. This suggests that the crust undergoing flexure beneath the basin was not thinned and this is consistent with the origin of the West Spitsbergen Fold Belt formed in a zone of intra-plate deformation prior to the separation of Greenland and the Barents Shelf in the Mid Cenozoic (Steel et al., 1985; Müller \& Spielhagen, 1990; Lyberis \& Manby, 1993a, 1993b; Maher et al., 1995; Manby \& Lyberis, 1996; Bergh et al., 1997; Braathen et al., 1999a, 1999b; Manby \& Lyberis, 2000; Bruhn \& Steel, 2003; Dörr et al., 2012).

The overall transgressive pattern within the Firkanten Fm indicates that the compression-related flexural subsidence exceeded the rate of sediment supply during this period. The major and minor flooding events may be related to pulses in the flexural subsidence occurring at different scales, resulting from episodes of tectonic shortening across the region. However, the structural history of the West Spitsbergen Thrust Belt during the Paleogene is not known in sufficient detail to ascertain whether a purely tectonic mechanism could be responsible for the variations in accommodation.

\section{Eustatic controls on sedimentation}

The unconformity at the base of the succession is not dated, but all of the succession that includes the Firkanten Fm and overlying Basilika and Grumantbyen Fms are considered to be Paleocene in age (Manum \& Throndsen, 1986; Dallmann, 1999). The absence of suitable material precludes further division of the succession using biostratigraphic evidence, and consequently it is not possible to directly correlate the succession with a published global sea-level curve such as those presented in Haq et al. (1987) or Miller et al. (2005). These curves show that there were global sea-level fluctuations during the Paleocene that can be expected to have affected sedimentation in the Central Tertiary Basin. The stratigraphic patterns recorded in the Firkanten Fm can therefore be considered in terms of global events in the Paleocene to provide some indications of the time period over which the succession was deposited.

The absence of evidence for an erosional sequence boundary and the lack of progradational patterns within parasequence sets suggest that the rate of tectonic subsidence was high enough to counterbalance any relative sea-level falls of global eustatic origin. Intervals of retrogradational parasequence patterns can be considered to have formed during periods of global sea-level rise or stillstand, whilst the aggradational patterns would have formed during periods when global sea level was falling, but at a rate slower than the flexural subsidence. According to Miller et al. (2005) there was a major sea-level fall of about $50 \mathrm{~m}$ in the early Paleocene (c. $63 \mathrm{Ma}$ ) and two major falls of about $25 \mathrm{~m}$ in late Paleocene times (at 60 and $56.5 \mathrm{Ma}$ ); there is also a fall at the Paleocene-Eocene boundary (Fig. 18). There is no evidence for relative sea-level falls of this magnitude within the Firkanten and Basilika Fms, so either they were completely masked by the tectonic subsidence, or they were deposited during an interval between major falls in sea level. The Grumantbyen Fm above shows a progradational pattern, and given its stratigraphic position just below the Paleocene-Eocene boundary, this package may correspond to 


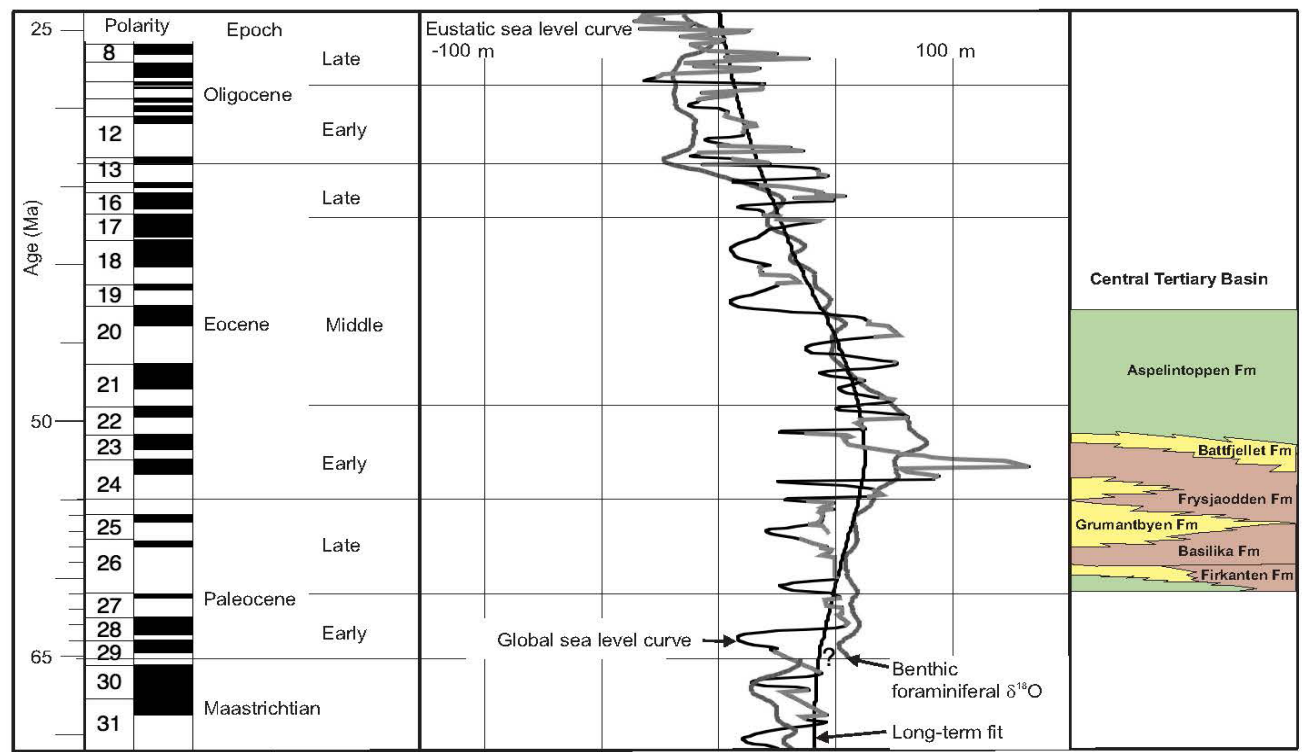

Figure 18 Global sea-level curve from Miller et al. (2005) with a possible correlation to the Van Mijenfjorden Group in the Central Tertiary Basin, as described further in the text.

either the sea-level fall at 56.5 Ma or the fall at $55 \mathrm{Ma}$. This would place the Firkanten-Basilika retrogradational succession as either occurring between the 60 and $56.5 \mathrm{Ma}$ or between 56.5 and $55 \mathrm{Ma}$ lowstand events.

These very approximate constraints on the period of deposition of the Firkanten and Basilika Fms provide some insights into the time period represented by the parasequences and parasequence sets that are recognised. If it is assumed that the conditions in the basin did not significantly change, with approximately the same rate of tectonic subsidence, sediment supply rate and similar depositional environments through Firkanten and Basilika Fms times, then the thickness of the studied interval (150 m) as a fraction of the total thickness of these formations (approximately $500 \mathrm{~m}$, Harland, 1997) is proportional to the time period in which it was deposited. Using these approximations, the 14 parasequence sets, each comprising between 2 and 5 parasequences of the studied interval, were deposited over a period of between 0.5 and 1.5 Ma. Each parasequence set would therefore have been deposited in between 35 and $100 \mathrm{ka}$, and each parasequence would have had between about $10 \mathrm{ka}$ and $30 \mathrm{ka}$ duration. The longer time periods approximate to $4^{\text {th }}$-order sea-level fluctuations for parasequence sets and 5th order for the parasequences (Miall, 1995); similar patterns have been recognised in the Alberta foreland basin (Plint, 1991).

\section{High-frequency sea-level fluctuations: evidence from coal seams}

An analysis of the organic (maceral) and inorganic (mineral) content of samples of coal from the Svea seam was undertaken to establish whether minor, high-resolution changes in accommodation could be detected from the stratigraphy of the seam (Fig. 6). Actively accumulating peats have a two-part structure, comprising a surficial, oxidising layer known as the acrotelm, and a lower, anaerobic layer known as the catotelm (Ingram, 1978; Clymo, 1984). The acrotelm-catotelm boundary defines the position of the permanent mire water-table and functions as the mire base-level, above which peat is produced, but also exposed to oxidation and degradation, and below which organic material is accommodated into the sedimentary record (Clymo, 1983; Diessel, 1992; Banerjee et al., 1996; Bohacs \& Suter, 1997). In a mire, when the accommodation rate is lower than organic productivity, 
the slow passage of accumulating plant debris through the acrotelm promotes desiccation, microbial or fungal oxidation or partial combustion of peat, so the resulting coals are generally higher in inertinite macerals (Diessel, 1992). When accommodation is balanced with the rate of organic productivity, plant material passes swiftly beneath base-level, where the reducing, low-pH conditions are conducive to the humification of lignin and cellulose (Diessel et al., 2000). Accommodation is mostly or entirely filled with plant material; hence, the resulting coal is low in detrital mineral content and high in vitrinite macerals (Diessel et al., 2000; Wadsworth et al., 2002). When accommodation begins to outpace organic productivity, allochthonous clastic sedimentation will take advantage of the excess accommodation that is not filled by autochthonous accumulation of organic material (Bohacs \& Suter, 1997; Diessel \& Gammidge, 1998; Diessel et al., 2000), and the resulting coal therefore has a high detrital mineral content. Finally, when accommodation entirely outpaces organic productivity, the mire is drowned, and replaced by lagoonal, lacustrine or marine conditions (Bohacs \& Suter, 1997; Diessel et al., 2000; Wadsworth et al., 2002). Hence, variations in the character, geometry and vertical succession of coal facies can be interpreted to reflect subtle changes in the accommodation conditions though the lifetime of a mire (e.g., Diessel, 1992; Banerjee et al., 1996; Petersen \& Andsbjerg, 1996; Diessel, 1998; Diessel \& Gammidge, 1998; Petersen et al., 1998; Diessel et al., 2000; Holz et al., 2002; Wadsworth et al., 2002, 2003; Davies et al., 2005, 2006; Silva et al., 2008; Jerrett et al., 2011a, 2001b).

The 47 analysed samples represent the majority of the stratigraphy of the seam in the Svea Nord mine, except for two major clastic splits in the coal that occur at $101-134 \mathrm{~cm}$ and $217-235 \mathrm{~cm}$ from the base of the seam. Additionally, two minor increments, at 25-35 and 205-208 cm from the base of the seam were not analysed (Fig. 6). In Fig. 6, the vertical profile of detrital mineral, pyrite, vitrinite, inertinite and liptinite content of the seam is shown. Maceral percentages are calculated on a mineral-free basis. It is apparent that the vitrinite and inertinite contents are inversely correlative and this is simply because the process of oxidation occurs at the expense of humification. The vitrinite content also mirrors the detrital mineral and pyrite content of the seam, strongly indicating that humification of plant material in the accumulating peat was promoted by high accommodation, which provided a medium for the transport of clastic sediments into the mire. Syngenetic pyrite precipitates in peat (and is subsequently preserved in coal) as a result of the bacterial reduction of sulphates in the presence of iron (Berner, 1970; Gluskoter, 1977; Berner et al., 1979; Price \& Shieh, 1979) and is therefore commonly used as an indicator for a marine or brackish influence on groundwater (Gluskoter, 1977; Price \& Shieh, 1979; Cohen et al., 1987; Brown \& Cohen, 1995; Petersen \& Andsbjerg, 1996; Staub, 2002). Its correlation with the vitrinite and detrital mineral content of the coal suggests that accommodation changes in the mire were largely controlled by subtle changes in relative sea level, which resulted in periodic, minor marine or brackish transgressions into the mire.

The vertical profile grossly reveals two cycles of increasing and then decreasing accommodation in the Svea paleomire. The basal $101 \mathrm{~cm}$ of the coal is characterised by a net increase in accommodation (increase in vitrinite, detrital mineral content and syngenetic pyrite), culminating in the deposition of a clastic split in the coal from 101 to $134 \mathrm{~cm}$. The high inertinite, and low vitrinite, detrital mineral and syngenetic pyrite content of the coal immediately overlying the clastic split at $134 \mathrm{~cm}$ suggests an abrupt decrease in accommodation overlying the clastic split. The coal in the interval $134-214 \mathrm{~cm}$ is also characterised by an increase in accommodation (increase in vitrinite, detrital mineral content and syngenetic pyrite), culminating in the deposition of a second clastic split in the coal from 214 to $235 \mathrm{~cm}$. The interval $235-310 \mathrm{~cm}$ displays an overall decrease in accommodation, marked by a general decrease in vitrinite, detrital mineral and pyrite content, and an overall increase in inertinite content. However, the trend is not particularly clear and two to three higher-frequency accommodation cycles may also be present at this interval.

The detailed petrology of the Svea seam indicates that very high-frequency accommodation cycles were probably occurring, the expression of which cannot be identified through much of the clastic 
sediments. The recognition of these higher-frequency fluctuations in relative sea level within the coal seam, which occurs within a single parasequence, indicates that time period for the shortest term relative sea-level changes was possibly 10 ka or less. These periodicities are consistent with Milankovitch cycle driven fluctuations in eustatic sea level, but in the context of a basin that was undergoing flexural subsidence throughout the period of deposition, pulses in the subsidence driven by fault movements near the basin margin are also likely to have contributed to the patterns of relative sea-level change.

\section{Discussion}

\section{Comparison with previous interpretation}

This study is the first comprehensive facies analyses of the Firkanten Fm to be published. Previous sedimentological investigations of the formation include many unpublished theses and reports, and the published interpretations, e.g., (Kellogg, 1975; Steel et al., 1981; Steel et al., 1985; Harland, 1997; Dallmann, 1999; Bruhn \& Steel, 2003; Nagy, 2005) are largely based on facies descriptions from them. Some of the observations and interpretations in the previous work are consistent with the new facies model, but they have reached a different conclusion regarding the overall depositional setting.

The previous general interpretation was that the Todalen $\mathrm{Mb}$ was formed in a fluvial-dominated delta-plain environment (Steel et al., 1981, 1985; Bruhn \& Steel, 2003) and this was largely based on the assumption that the conglomeratic beds in the Firkanten Fm are related to the fluvial Grønfjorden Bed. However, the Grønfjorden Bed occurs only in the western side of the basin (Kellogg, 1975) and in this study an important distinction has been made between the extrabasinal clast and intrabasinal mudclast conglomerates (Cgp and Cgm) and the depositional settings in which they formed. The Endalen Mb has been interpreted by previous authors as a delta-front succession (Steel et al., 1981; Steel \& Worsley, 1984; Bruhn \& Steel, 2003) based on its stratigraphic position relative to the Todalen Mb, which was considered to be a delta-plain succession.

The key differences between the present and previous interpretations are summarised below and are given in Table 1.

\section{Flood plain vs. coastal plain}

Carbonaceous mudstone and coal of the Todalen $\mathrm{Mb}$ (equivalent to facies $\mathrm{Mk}$ and $\mathrm{K}$ ) have previously been interpreted as floodplain or interdistributary bay deposits (Steel et al., 1981) on the basis of the fine grain size and the high organic content. Mudstone beds similar to facies Ms and Mk have been described as non-marine, flood basin and levee accumulations (Nøttvedt, 1982) where the coal was deposited in areas of low clastic input. This environment would have resulted in small and patchy coal beds interrupted in places by fluvial clastics.

In the most recent study of the Todalen Mb (Nagy, 2005), it was suggested that the mudstones of facies Mk and Ms were deposited in lakes, swamps and lagoons during rising sea level based on marine influence, high organic content and barren foraminifera. This is consistent with the conclusions of the present study. 


\section{Tidally influenced lagoon vs. estuary or tidally influenced delta} plain

Heterolithic mudstone and sandstone similar to facies Sh have been interpreted as tidally influenced submarine levees or interdistributary bays of a delta with limited tide and wave influence (Steel et al., 1981; Steel \& Worsley, 1984). Beds equivalent to facies Mk and Ms have been described as tidal mud-flat (Nøttvedt, 1982) or lagoonal (Nagy, 2005) deposits. The tidally influenced sections have also been considered to be estuary deposits (Nøttvedt, 1982); however, this is considered unlikely since no evidence has been found for valley incision or fluvial deposits associated with the tidally-influenced facies. The marine indications in this facies are obvious and the overall transgression contradicts a fluvial prograding system.

\section{Barrier bars vs. crevasse splays}

The sandstone beds in the Firkanten Fm have previously been separated into two different settings; crevasse splays or fluvial channels on a delta plain in the Todalen Mb and barrier bars/mouth bars of a delta front in the Endalen Mb (Kellogg, 1975; Steel et al., 1981). Poorly sorted sandstones with organic material (facies Sk and Sr) have been described as crevasse splay or fluvial levee deposits on a delta plain (Nøttvedt, 1982), but they have also been interpreted as parts of a lagoonal succession (Nagy, 2005). The well-sorted sandstone sections with pebbly laminae (similar to FA3) were interpreted as fluvial channel fill in the Todalen $\mathrm{Mb}$, with the presence of Ophiomorpha indicating a marginal marine setting (Nøttvedt, 1982). In this present study and in Nagy (2005), these facies are considered to be the deposits of beach/barrier bars. Previous interpreters did not recognise the abundance of marine indicators in these deposits (i.e., glauconite and ichnological assemblages) and they were not assessed in either a facies association or a sequence-stratigraphic context.

\section{Foreshore vs. fluvial channel}

The delta interpretation from previous workers was based on the close relationship to the non-marine facies of FA1 and the presence of pebbles interpreted as channel lag (Nøttvedt, 1982). Conglomerate beds were interpreted as fluvial mainly on the basis of comparison with the Grønfjorden Bed and not considered in a context of the facies association in which they occurred. However, the pebbly layers occur in many parts of the succession as parts of tabular beds, and occur not only at the bases of the beds. The thin pebbly laminae were interpreted as crevasse splays or fluvial chute bars (Nøttvedt, 1982) but they have a similar appearance to gravelly foreshore/shoreface deposits described by Hart \& Plint $(1989,1995,2003)$. Furthermore, no distinction was made between conglomerate beds composed of extrabasinal clasts and beds of angular mudclasts (Steel et al., 1981; Bruhn \& Steel, 2003).

Channel geometries are very rarely observed in the field and the geometries found are thin and wide. No evidence has been found in the field for fluvial channel deposition. In core, minor channels are harder to identify but there is no clear evidence of fluvial channel deposition. Where there are lenticular packages of beds, they display wave-ripple and low-angle cross-lamination, hummocky and swaley crossstratification, or evidence of tidal influence. They are therefore considered to be deposits of a foreshore/shoreface setting (cf., Hart \& Plint, 1989, 1995, 2003) or some minor tidal channels. 


\section{Shoreface vs. delta front}

Bioturbated sandstone with hummocky and swaley cross-stratification similar to facies $\mathrm{SI}$ and $\mathrm{Sb}$ of FA4 has been described from the Firkanten Fm and interpreted as shoreface or upper delta front (Nøttvedt, 1982; Bruhn \& Steel, 2003; Nagy, 2005). The bioturbated sandstone was interpreted as a lower delta-front or prodelta/offshore transition based on the relationship to the interpreted delta plain of Todalen Mb. However, intense bioturbation and glauconite are possible indications of low sedimentation rates and are not commonly associated with delta-front deposits.

\section{Basin setting for coal formation}

In previous work on the Central Tertiary Basin, the Palaeocene coal-bearing strata were interpreted as the deposits of a progradational deltaic system that built out from the eastern side of the basin in central Spitsbergen (Worsley et al., 1986; Bruhn \& Steel, 2003). The new facies analysis proposes a coastal plain environment where rheotrophic and ombrotrophic mires were sites of extensive and thick peat accumulations in the eastern part of the basin. Analysis of the coals shows that these mires received very low clastic input through much of their formation, supporting the view that they represent the product of mires that were partly raised, i.e., ombrotrophic systems. The correlation of syngenetic pyrite, clastic sediment and vitrinite content within the Svea seam strongly implies a depositional setting near a coastline for the original mire, and that clastic partings within the coal were deposited as a result of episodic marine flooding of the mire. This interpretation is supported by the presence of glauconite in the sandstones in the succession that reveal a shallow-marine source for some of the clastic sediment.

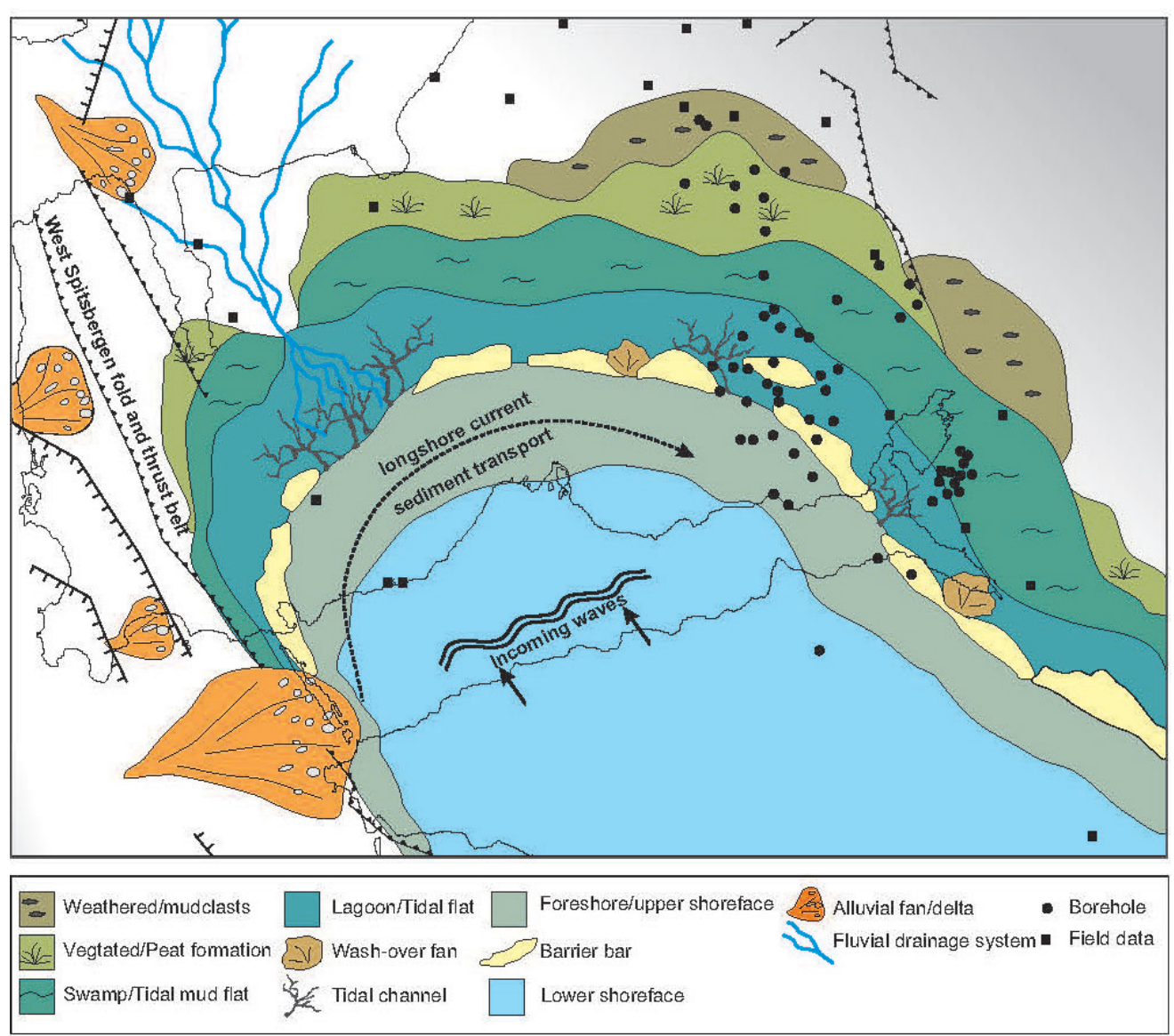

Figure 19 Regional paleogeographic reconstruction of the Central Tertiary Basin showing the sedimentary transport pattern, fluvial drainage and interpretation of the environmental setting. 
A peripheral forebulge on the eastern margin of the basin has been suggested as a source of sediment (Bruhn \& Steel, 2003); however, uplift of a forebulge is approximately $10 \%$ of the subsidence in the basin at a thrust front (Allen \& Allen, 2005) and a major sediment source other than the forebulge would have been required to maintain continental to shallow-marine deposition in the subsiding basin. Dörr et al. (2013) also concluded that the forebulge had a very minor uplift due to the rigidity of the continental crust on Svalbard and could therefore not have contributed to the sediment supply to the Firkanten Fm. Areas of eroded Mesozoic strata in northern Spitsbergen (Dörr et al., 2012) are considered to be the main source of sand to the basin, supplied via rivers to the western margin and transported by wave, storm and some tidal processes along a shoreline oriented NW-SE (Fig. 19). Pebbly material was additionally supplied from the West Spitsbergen Fold Belt to the west and deposited as pebbly shoreface sediments on marine flooding surfaces. The orientation of the coast, as indicated in Fig. 19, shows an embayment opening up towards the south and closed to the north by the uplifted area (Dörr et al., 2012) and to the west by West Spitsbergen Fold Belt. The eastern side was most probably just at base level (Dörr et al., 2012) by the peripheral bulge uplift and would therefore be the limitation of the marine embayment. This is in line with the conclusions from Jochmann et al. (2019) with a late development of an extending coastline along the eastern side and reaching towards the north.

Flexural subsidence is considered to be the most likely mechanism for the creation of accommodation in the Central Tertiary Basin that was greatest on the western side of the basin adjacent to the uplifted West Spitsbergen Fold Belt (Dörr et al., 2013; Helland-Hansen, 1990). Paleogeographic reconstructions show the orientation of the coastline gradually changing from west-east to northwest-southeast. This pattern can be attributed to asymmetric subsidence in the basin, as sedimentation was more able to keep pace with the generation of accommodation where flexural subsidence was lowest.

Extensive peat mires developed on the eastern side of the basin where subsidence rates were lower, and for periods of time there was a balance between creation of accommodation and the vertical growth of peat mires to create coal seams up to 5 metres thick. High-frequency fluctuations in the amount of accommodation generated during mire accumulation are indicated by changes in the proportions of inertinite and vitrinite macerals within an individual seam. Termination of mire development occurred when marine flooding of the coastal plain occurred, resulting in the rate of accommodation creation exceeding peat formation (Bohacs \& Suter, 1997; Davies et al. 2005). These flooding events deposited beach barrier and foreshore sands on top of the peat. Two orders of marine flooding surface are recognised; minor flooding surfaces that re-established the shoreline in a similar position to the previous flooding event, and major marine flooding surfaces that resulted in a landward shift of the facies belts by 10 to $15 \mathrm{~km}$. The increased accommodation that caused the marine flooding was probably a result of a combination of changes in the rate of tectonic subsidence and global eustatic sea-level fluctuations. Approximate calculations of the time periods between the flooding events are consistent with orbital-forced climate fluctuations affecting global eustacy, but tectonic controls cannot be excluded in an actively subsiding basin.

The stratigraphic framework and the paleogeographic models provide a basis for predicting the distribution of coal seams within the Central Tertiary Basin that may be applied to other flexural basins with coastal-plain peat formation. The 'foreland' margin where flexural subsidence is lowest is a favourable site for long-term mire development because peat accumulation is more able to keep pace with the creation of accommodation; this margin will also have the lowest clastic input if sediment supply is from the margin adjacent to the uplift, or is supplied axially to the basin, and this will favour peat formation (Bohacs \& Suter, 1997) as found in the Firkanten Fm. During periods when the long-term creation of accommodation exceeds sediment accumulation there will be a retrogradational pattern of facies as transgression proceeds. In the case of the Central Tertiary Basin, transgression was towards the north and consequently the coastal-plain environment where peat was forming also stepped north- 
ward through time. The higher stratigraphic position of the Longyear seam in the north compared to the Svea seam in the south is a reflection of this, as well as the younger successions found even farther to the north like the Askeladden and Svarteper coal seams. Further coal seams may therefore be expected to occur at lower stratigraphic levels in the south and at higher levels to the north; they may also be expected to occur on the eastern side of the basin where the strata have not been eroded.

\section{Conclusions}

A transgressive, wave-dominated coastline for the entire Firkanten and Basilika formations is sug gested, rather than the previous models involving a fluvial delta system transitional to a wavedominated coast.

The coal and carbonaceous mudstone of the Todalen $\mathrm{Mb}$ were deposited on the sheltered coastal plain in partly raised mires and swamps which gradually extended seaward into lagoons and tidal flats.

The paralic environment was protected by barrier bars from wave and storm influence and the sanddominated foreshore and beach at the seaward side of the bars show typical wave and storm influence.

The fluvial input to this system is suggested to have been minor and occurred only in the western part of the basin (the Grønfjorden Bed).

Gravelly material was mainly deposited as part of storm events that also brought material into the lagoons to form wash-over fans.

\section{Basin analysis}

Correlation of coal-bearing strata in the Central Tertiary Basin of Spitsbergen using the sequencestratigraphic approach of identifying parasequences proved to be an effective analytical method. Consideration of the likely width of facies belts helped to constrain the analysis and the differences in the characteristics of different coal seams have also provided marker horizons within the succession.

The stratigraphic analysis reveals an overall transgressive succession that can be divided into parasequence sets which show aggradational and retrogradational patterns. There are no progradational parasequence sets and no evidence for a relative sea-level fall in the form of incised surfaces

Long-term accommodation was determined by flexural subsidence caused by a crustal fold in a compressional intraplate setting. Variations in the rate of tectonic subsidence may have resulted in short-term variations in accommodation, but a global eustatic sea-level signature is also considered to be present.

A series of paleogeographic reconstructions show a shoreline stepping northwards through the basin and rotating from W-E to NW-SE as transgression proceeded through the Firkanten Fm.

Coal seams occur mainly in the eastern part of the basin, where clastic input was limited and the flexural subsidence was lowest. Changes in accommodation can be recognised within coal seams and peat accumulation was terminated when marine flooding occurred. 
Acknowledgements. SNSK (Store Norske Spitsbergen Kulkompani) is thanked for providing access to their data records, core store facilities and the mines in Longyearbyen and Svea Nord. Charlotta Lüthje would also like to thank SNSK for providing funding for a PhD project carried out at UNIS, Royal Holloway, University of London and at the University of Bergen.

\section{References}

Allen, J.R.L., 1990: The formation of coastal peat marshes under an upward tendency of relative sea-level. Journal of the Geological Society of London 147, 743-745. https://doi.org/10.1144/gsjgs.147.5.0743.

Allen, P.A. \& Allen, J.R., 2005: Basin Analysis. Principles and Applications. Blackwell Publishing, Oxford, 560 pp.

Banerjee, I., Kalkreuth, W. \& Davies, E.H., 1996: Coal seam splits and transgressive-regressive coal couplets: A key to stratigraphy of high-frequency sequences. Geology 24, 1001-1004.

https://doi.org/10.1130/0091-7613(1996)024<1001:CSSATR>2.3.CO;2.

Bergh, S.G., Braathen, A. \& Andresen, A., 1997: Interaction of basement involved and thin-skinned tectonism in the Tertiary fold-thrust belt of central Spitsbergen, Svalbard. American Association of Petroleum Geologists Bulletin 81, 637-661.

Berner, R.A., 1970: Sedimentary pyrite formation. Americal Journal of Science 268, 1-23.

https://doi.org/10.2475/ajs.268.1.1.

Berner, R.A., Baldwin, T. \& Holdren, G.R., 1979: Authigenic iron sulfides as paleosalinity indicators. Journal of Sedimentary Research 49, 1345-1350.

https://doi.org/10.1306/212F7923-2B24-11D7-8648000102C1865D.

Blythe, A.E. \& Kleinspehn, K.L., 1998: Tectonically versus climatically driven Cenozoic exhumation of the Eurasian plate margin, Svalbard: fission track analyses. Tectonics 17, 621-639. https://doi.org/10.1029/98TC01890.

Bohacs, K., \& Suter, J., 1997: Sequence stratigraphic distribution of coaly rocks: Fundamental controls and paralic examples. American Association of Petroleum Geologists Bulletin 81, 1612-1639.

Boyd, R., Dalrymple, R. \& Zaitlin, B.A., 1992: Classification of clastic coastal depositional environments. Sedimentary Geology 80, 139-150. https://doi.org/10.1016/0037-0738(92)90037-R.

Braathen, A., Bergh, S.G. \& Maher, H.D., 1999a: Application of a Critical Wedge Taper Model to the Tertiary Transpressional Fold-Thrust Belt on Spitsbergen, Svalbard. Geological Society Of America Bulletin 111, 1468-1485.

Braathen, A., Bergh, S., Karlsen, F., Maher, H., Andresen, A., Hansen, A.I. \& Bergvik, A., 1999b: Kinematics of the Isfjorden-Ymerbukta Fault Zone: A Dextral Oblique-Thrust Ramp in the Tertiary Fold-Thrust Belt of Spitsbergen. Norsk Geologisk Tidsskrift 79, 227-239. https://doi.org/10.1080/002919699433681.

Brown, K.E. \& Cohen, A.D., 1995: Stratigraphic and micropetrographic occurrences of pyrite in sediments at the confluence of carbonate and peat-forming depositional systems, southern Florida, U.S.A. Organic Geochemistry 22, 105-126. https://doi.org/10.1016/0146-6380(95)90011-X. 
Bruening, E.F., 1990: Oligotrophic forested wetlands in Borneo. In Goodall, D.W. (ed.): Ecosystems of the World: Forested Wetlands, Elsevier, pp. 299-334.

Bruhn, R. \& Steel, R., 2003: High-resolution sequence stratigraphy of a clastic foredeep succession (Paleocene, Spitsbergen): An example of peripheral-bulge-controlled depositional architecture. Journal of Sedimentary Research 73, 745-755. https://doi.org/10.1306/012303730745.

Carr, A.P., 1971: Experiments on longshore transport and sorting of pebbles Chesil Beach, England. Journal of Sedimentary Petrology 41, 1084-1104.

https://doi.org/10.1306/74D7240A-2B21-11D7-8648000102C1865D

Catuneanu, O., 2002: Geological Society of Africa Presidential Review No. 1 Sequence stratigraphy of clastic systems: concepts, merits, and pitfalls. Journal of African Earth Sciences 35, 1-43. https://doi.org/10.1016/S0899-5362(02)00004-0.

Cepek, P., 2001: Paleogene calcareous nannofossils from the Firkanten and Sarsbukta Formations on Spitsbergen. In Tessensohn, F. (ed.): Intra-continental fold belts; Case 1: West Spitsbergen, Geologisches Jahrbuch, Polar Issue No. 7, 535-547.

Cepek, P. \& Kruttzsch, W., 2001: Conflicting Interpretations of Tertiary biostratigraphy of Spitsbergen and new palynological results. In Tessensohn, F. (ed.): Intra-continental fold belts; Case 1: West Spitsbergen, Geologisches Jahrbuch, Polar Issue No. 7, 551-599.

Clymo, R.S., 1983: Peat. In Gore, A.J.P. (ed.): Mires: Swamp, Bog, Fen and Moor, Elsevier, pp. 159-224.

Clymo, R.S., 1984: The limits to peat bog growth. Philosophical Transactions of the Royal Society of London Series B-Biological Sciences 303, 605-654. https://doi.org/10.1098/rstb.1984.0002.

Clymo, R.S., 1987: Rainwater-fed peat as a precursor of coal. In Scott, A.C. (ed.): Coal and Coal-Bearing Strata: Recent Advances, Geological Society of London Special Publication 32, pp. 107-125. https://doi.org/10.1144/GSL.SP.1987.032.01.03.

Cmiel, S.R. \& Fabianska, M.J., 2004: Geochemical and petrographic properties of some Spitsbergen coals and dispersed organic matter. International Journal of Coal Geology 57, 77-97. https://doi.org/10.1016/j.coal.2003.09.002.

Cohen, A.D., Spackman, W. \& Raymond Jr., R., 1987: Interpreting the characteristics of coal seams from chemical, physical and petrographic studies of peat deposits. In Scott, A.C. (ed.): Coal and Coal-Bearing Strata: Recent Advances, Geological Society of London Special Publication 32, pp. 17-23. https://doi.org/10.1144/GSL.SP.1987.032.01.08.

Collinson, J.D., 1996: Alluvial sediments. In Reading, H.G. (ed.): Sedimentary Environments: Processes, Facies and Stratigraphy, 3rd edition, Blackwell Science, pp. 232-280.

Cross, T.A., 1988: Controls on coal distribution in transgressive-regressive cycles. Upper Cretaceous, Western Interior, USA. In Wilgus, C.K., Hastings, B.S., Ross, C.A., Posamentier, H.W., Van Wagoner, J.C. \& Kendall, C.G.St.C. (eds.): Sea Level Changes: An Integrated Approach. SEPM Special Publication No. 42, pp. 371-380. https://doi.org/10.2110/pec.88.01.0371.

Dallmann, W.K., 1999: Lithostratigraphic lexicon of Svalbard. Norsk Polarinstitutt, 318 pp. 
Dalrymple, R.W., 1992: Tidal depositional systems. In Walker, R.G. \& James, N.P. (eds.): Facies Models: response to sea level change. Geological Association of Canada, 409 pp.

Davies, R.C., Diessel, C., Howell, J., Flint, S.S. \& Boyd, R., 2005: Vertical and lateral variation in the petrography of the Upper Cretaceous Sunnyside coal of eastern Utah, USA: implications for the recognition of high-resolution accommodation changes in paralic coal seams. International Journal of Coal Geology 61, 13-33. https://doi.org/10.1016/j.coal.2004.06.003.

Davies, R., Howell, J., Boyd, R., Flint, S. \& Diessel, C., 2006: High-resolution sequence-stratigraphic correlation between shallow-marine and terrestrial strata: Examples from the Sunnyside Member of the Cretaceous Blackhawk Formation, Book Cliffs, Eastern Utah. Bulletin of the American Association of Petroleum Geologists 90, 1121-1140. https://doi.org/10.1306/02210604077.

Diessel, C., 1992: Coal-bearing Depositional Systems. Springer-Verlag, Germany, 721 pp. https://doi.org/10.1007/978-3-642-75668-9.

Diessel, C., 1998: Sequence stratigraphy applied to coal seams: two case histories. In Shanley, K.W., \& McCabe, P.J. (eds.): Relative Role of Eustacy, Climate and Tectonism in Continental Rocks. SEPM Special Publication 59, pp. 151-173. https://doi.org/10.2110/pec.98.59.0150.

Diessel, C., 2007: Utility of coal petrology for sequence-stratigraphic analysis. International Journal of Coal Geology 70, 3-34. https://doi.org/10.1016/j.coal.2006.01.008.

Diessel, C.F.K. \& Gammidge, L., 1998: Isometamorphic variations in the reflectance and fluorescence of vitrinite - a key to depositional environment. International Journal of Coal Geology 36, 167-222. https://doi.org/10.1016/S0166-5162(98)00003-2.

Diessel, C., Boyd, R., Wadsworth, J., Leckie, D. \& Chalmers, G., 2000: On balanced and unbalanced accommodation/peat accumulation ratios in the Cretaceous coals from Gates Formation, Western Canada, and their sequence-stratigraphic significance. International Journal of Coal Geology 43, 143186. https://doi.org/10.1016/S0166-5162(99)00058-0.

Dörr, N., Lisker, F., Clift, P.D., Carter, A., Gee, D.G., Tebenkov, A.M. \& Spiegel, C., 2012: Late MesozoicCenozoic exhumation history of northern Svalbard and its regional significance: Constraints from apatite fission track analysis. Tectonophysics 514-517, 81-92. https://doi.org/10.1016/j.tecto.2011.10.007.

Dörr, N., Clift, P.D., Lisker, F. \& Spiegel, C., 2013: Why is Svalbard an island? Evidence for two-stage uplift, magmatic underplating, and mantle thermal anomalies. Tectonics 32, 473-486. https://doi.org/10.1002/tect.20039.

Einsele, G., 2000: Sedimentary Basins; Evolution, Facies, and Sediment Budget. Second edition. Springer-Verlag, Berlin, 792 pp.

Ekdale, A.A., Bromley, R.G. \& Pemberton, S.G., 1984: Ichnology: the use of trace fossils in sedimentology and stratigraphy. SEPM Short Course Notes 15, 317 pp. https://doi.org/10.2110/scn.84.15.

Fielding, C.R., 1985: Coal depositional models and the distinction between alluvial and delta plain environments. Sedimentary Geology 42, 41-48. https://doi.org/10.1016/0037-0738(85)90072-7.

Gluskoter, H.J., 1977: Inorganic sulfur in coal. Energy Sources 3, 125-13.

https://doi.org/10.1080/00908317708945974. 
Golovneva, L.B., 2000: Palaeogene climates of Spitsbergen. GFF The Geological Society of Sweden 122, 62-63. https://doi.org/10.1080/11035890001221062.

Haq, B.U., Hardenbol, J. \& Vail, P.R., 1987: Chronology of fluctuating sea levels since the Triassic. Science 235, 1156-1167. https://doi.org/10.1126/science.235.4793.1156.

Harland, W.B., 1997: The Geology of Svalbard. Geological Society of London Memoir, 17, 521 pp. https://doi.org/10.1144/GSL.MEM.1997.017.01.01.

Hart, B.S. \& Plint, A.G., 1989: Gravelly shoreface deposits: a comparison of modern and ancient facies sequences. Sedimentology 36, 551-557. https://doi.org/10.1111/j.1365-3091.1989.tb02085.x.

Hart, B.S. \& Plint, A.G., 1995: Gravely shoreface and beach face deposits. In Plint, A.G. (ed.): Clastic Facies Analysis - a Tribute to the Research and Teaching of Harold G. Reading. International Association of Sedimentologists Special Publication 22, pp. 75-99. https://doi.org/10.1002/9781444304091.ch4.

Hart, B.S. \& Plint, A.G., 2003: Stratigraphy and sedimentology of shoreface and fluvial conglomerates: insights from the Cardium Formation in NW Alberta and adjacent British Columbia. Bulletin of Canadian Petroleum Geology 51, 437-464. https://doi.org/10.2113/51.4.437.

Helland-Hansen, W., 1990: Sedimentation in Paleogene Foreland Basin, Spitsbergen. American Association of Petroleum Geologists Bulletin 74, 260-272. https://doi.org/10.1306/0C9B22BD-1710-11D7-8645000102C1865D.

Holz, M., Kalkreuth, W. \& Banerjee, I., 2002: Sequence stratigraphy of paralic coal-bearing strata: an overview. International Journal of Coal Geology 48, 147-179. https://doi.org/10.1016/S0166-5162(01)00056-8.

Huddle, J.W. \& Patterson, S.H., 1961: Origin of Pennsylvanian underclay and related seat rocks. Geological Society of America Bulletin 72, 1643-1660. https://doi.org/10.1130/0016-7606(1961)72[1643:OOPUAR]2.0.CO;2.

Ingram, H.A.P., 1978: Soil layers in mires - function and terminology. Journal of Soil Science 29, $224-227$. https://doi.org/10.1111/j.1365-2389.1978.tb02053.x.

Jerrett, R.M., Flint, S.S., Davies, R. \& Hodgson, D.M., 2011a: Sequence stratigraphic interpretation of a Pennsylvanian (Upper Carboniferous) coal from the central Appalachian Basin, USA. Sedimentology 58, 1180-1207. https://doi.org/10.1111/j.1365-3091.2010.01200.x.

Jerrett, R.M., Hodgson, D.M., Flint, S.S \& Davies, R.C., 2011b: Relative sea-level and climatic control on coal character in the Westphalian C (Atokan) Four Corners Formation, central Appalachian Basin, USA. Journal of Sedimentary Research 81, 420-445. https://doi.org/10.2110/jsr.2011.37.

Jochmann, M., 2004: The geology of the Ispallen area, Svalbard, with emphasis on the coal bearing Firkanten Formation. Diploma. Ludwig Maximilians Universität, München, 88 pp.

Jochmann, M.M., Augland, L.E., Lenz, O., Bieg, G., Haugen, T., Grundvåg, S.A., Jelby, M.E., Midtkandal, I., Dolezych M. \& Hjálmarsdóttir, H.R., 2019: Sylfjellet: a new outcrop of the Paleogene Van Mijenfjorden Group in Svalbard. Arktos, 22 pp. https://doi.org/10.1007/s41063-019-00072-w. 
Johannessen P.N., Dybkjær, K., Andersen, C., Kristensen, L., Hovikoski, J., Vosgerau, H., 2010: Architecture of an Upper Jurassic barrier island sandstone reservoir, Danish Central Graben: implications of a Holocene-Recent analogue from the Wadden Sea. In: Vining B.A. and S.C. Pickering (eds): Petroleum Geology: From Mature Basins to New Frontiers - Proceedings of the 7th Petroleum Geology Conference, pp. 145-155. https://doi.org/10.1144/0070145.

Johnson, H.D. \& Baldwin, C.T., 1996: Shallow clastic seas. In Reading, H.G. (ed.): Sedimentary Environments: Processes, Facies and Stratigraphy 3rd edition. Blackwell Science, pp. 232-280.

Kamola, D.L. \& Van Wagoner, J.C., 1995: Stratigraphy and facies architecture of parasequences with examples from the Spring Canyon Member, Blackhawk Formation, Utah. In Van Wagoner, J.C. \& Bertram, G.T. (eds.): Sequence Stratigraphy of Foreland Basin Deposits. American Association of Petroleum Geologists Memoir, 64, pp. 27-54.

Kellogg, H.E., 1975: Tertiary Stratigraphy and tectonism in Svalbard and continental drift. American Association of Petroleum Geologists Bulletin 59, 465-485. https://doi.org/10.1306/83D91CB3-16C7-11D7-8645000102C1865D.

Kostro, F., 2005: Character of the basal unconformity of the Paleocene successions in the Central Basin, Svalbard. Diplom, University of Freiberg, Freiberg, 106 pp.

Leckie, D.A. \& Walker, R.G., 1982: Storm-dominated and tide-dominated shorelines in Cretaceous Moosebar-Lower Gates interval - outcrop equivalents of deep basin gas trap in Western Canada. American Association of Petroleum Geologists Bulletin 66, 138-157. https://doi.org/10.1306/03B59A53-16D1-11D7-8645000102C1865D.

Lyberis, N. \& Manby, G., 1993a: The Origin of the West Spitsbergen Fold Belt from Geological Constraints and Plate Kinematics - Implications for the Arctic. Tectonophysics 224, 371-391. https://doi.org/10.1016/0040-1951(93)90039-M.

Lyberis, N. \& Manby, 1993b: The West Spitsbergen Fold Belt - the Result of Late Cretaceous-Paleocene Greenland-Svalbard Convergence. Geological Journal 28, 125-136.

https://doi.org/10.1002/gj.3350280203.

Lüthje, C.J., Milàn, J. \& Hurum, J.H., 2010: Paleocene Tracks of the Mammal Pantodont Genus Titanoides in Coal-Bearing Strata, Svalbard, Arctic Norway. Journal of Vertebrate Paleontology, 30, 521-527. https://doi.org/10.1080/02724631003617449.

Maher, H., 2001: Manifestations of the Cretaceous High Arctic Large Igneous Province in Svalbard. The Journal of Geology 109, 91-104. https://doi.org/10.1086/317960.

Maher, H.D., Braathen, A., Bergh, S., Dallmann, W. \& Harland, W.B., 1995: Tertiary or Cretaceous Age for Spitsbergen's Fold-Thrust Belt on the Barents Shelf. Tectonics 14, 1321-1326.

https://doi.org/10.1029/95TC01257.

Manby, G. \& Lyberis, N., 1996: State of Stress and Tectonic Evolution of the West Spitsbergen Fold Belt. Tectonophysics 267, 1-29. https://doi.org/10.1016/S0040-1951(96)00109-6.

Manby, G. \& Lyberis, N., 2000: Pre-Ocean Opening Compression of the Northwestern Atlantic Margin: Evidence from Eastern North Greenland. Journal of the Geological Society of London 157, 707-710. https://doi.org/10.1144/jgs.157.4.707. 
Manum, S.B. \& Throndsen, T., 1978: Rank of coal and dispersed organic matter and its geological bearing in the Spitsbergen Tertiary. Norsk Polarinstitutt Aarbok 1977, pp. 159-177.

Manum, S.B. \& Throndsen, T., 1986: Age of Tertiary formations on Spitsbergen. Polar Research 4, 103131. https://doi.org/10.1111/j.1751-8369.1986.tb00526.x.

Marshall, C., Uguna, J., Large, D.J., Meredith, W., Jochmann, M., Friis, B., Vane, C.H., Spiro, B.F., Snape, C.E., Orheim, A., 2015: Geochemistry and petrology of palaeocene coals from Spitzbergen - Part 2: Maturity variations and implications for local and regional burial models. International Journal of Coal Geology 143, 1-10. https://doi.org/10.1016/j.coal.2015.03.013.

McCabe, P.J., 1984: Depositional environments of coal and coal-bearing strata. In Rahmani, R.A. \& Flores, R.M. (eds.): Sedimentology of coal and coal-bearing sequences. International Association of Sedimentologists Special Publication 7, pp. 13-42.

McCabe, P.J. \& Shanley, K.W., 1992: Organic control on shoreface stacking patterns - bogged down in the mire. Geology 20, 741-744. https://doi.org/10.1130/0091-7613(1992)020<0741:OCOSSP>2.3.CO;2.

Miall, A.D., 1995: Whither stratigraphy? Sedimentary Geology 100, 5-20.

https://doi.org/10.1016/0037-0738(95)00100-X.

Miller, K.G., Kominz, M.A., Browning, J.V., Wright, J.D., Mountain, G.S., Katz, M.E., Sugarman, P.J., Cramer, B.S., Christie-Blick, N. \& Pekar, S.F., 2005: The Phanerozoic record of global sea-level change. Science 310, 1293-1298. https://doi.org/10.1126/science.1116412.

Moore, T.A. \& Shearer, J.C., 2003, Peat/coal type and depositional environment - are they related? International Journal of Coal Geology 56, 233-252. https://doi.org/10.1016/S0166-5162(03)00114-9.

Müller, R.D. \& Spielhagen, R.F., 1990: Evolution of the Central Tertiary Basin of Spitsbergen - Towards a Synthesis of Sediment and Plate Tectonic History. Palaeogeography Palaeoclimatology Palaeoecology 80, 153-172. https://doi.org/10.1016/0031-0182(90)90127-S.

Nagy, J., 1966: Preliminary report on the geology of Eastern Torell Land, Vestspitsbergen. Norsk Polar Institutt Årsbok 1964, pp. 69-72.

Nagy, J., 2005: Delta-influenced foraminiferal facies and sequence stratigraphy of Paleocene deposits in Spitsbergen. Palaeogeography, Palaeoclimatology, Palaeoecology 222, 161-179. https://doi.org/10.1016/j.palaeo.2005.03.014.

Nagy, J., Tovar F.J.R. \& Reolid, M., 2016: Environmental significance of Ophiomorpha in a transgressive-regressive sequence of the Spitsbergen Paleocene. Polar Reseach 35, 16 pp. https://doi.org/10.3402/polar.v35.24192.

Nøttvedt, A., 1982: Characteristics and evolution of the Askeladden deltaic sequence (Paleocene) on Spitsbergen - with comparison to the Ravenscar Group deltaic sequence (Bajocian) of Northeast England. Dr.Scient, University of Bergen, 137 pp.

Orheim, A., Bieg, G., Brekke, T., Horseide, V. \& Stenvold, J., 2007: Petrography and geochemical affinities of Spitsbergen Paleocene coals, Norway. International Journal of Coal Geology 70, 116-136. https://doi.org/10.1016/j.coal.2006.04.008. 
Pemberton, S.G. \& MacEachern, J.A., 1995: The sequence stratigraphic significance of trace fossils in examples from the Cretaceous of Alberta. In Van Wagoner, J.A. \& Bertram, G.T. (eds.): Sequence Stratigraphy of Foreland Basin Deposits - Outcrop and Subsurface Examples from the Cretaceous of North America. American Association of Petroleum Geologists Memoir 64, pp. 429-475.

Pemberton, S.G., MacEachern, J.A. \& Frey, R.W., 1992: Trace fossil facies models: Environmental and allostratigraphic signiphicance. In Walker, R.G. \& James, N.P. (eds.): Facies Models: response to sea level change. Geological Association of Canada, St Johns, pp. 47-72.

Petersen, H.I. \& Andsbjerg, J., 1996: Organic facies development within Middle Jurassic coal seams, Danish Central Graben, and evidence for relative sea-level control on peat accumulation in a coastal plain environment. Sedimentary Geology 106, 259-277. https://doi.org/10.1016/S0037-0738(96)00015-2.

Petersen, H.I., Bojesen-Koefoed, J.A., Nytoft, H.P., Surlyk, F., Therkelsen, J. \& Vosgerau, H., 1998: Relative sea-level changes recorded by paralic liptinite enriched coal facies cycles, Middle Jurassic Muslingebjerg Formation, Hochstetter Forland, Northeast Greenland. International Journal of Coal Geology 36, 1-30. https://doi.org/10.1016/S0166-5162(97)00032-3.

Plint, A.G., 1991: High-frequency relative sea-level oscillations in Upper Cretaceous shelf clastics of the Alberta foreland basin: possible evidence for a glacio-eustatic 34 control? In Macdonald, D.I.M. (ed.): Sedimentation, Tectonics and Eustacy. International Association of Sedimentologists, Special Publication 12, pp. 409-428. https://doi.org/10.1002/9781444303896.ch22.

Plint, A.G. \& Norris, B., 1991: Anatomy of a ramp margin sequence: facies successions, paleogeography, and sediment dispersal patterns in the Muskiki and Marshybank formations, Alberta Foreland Basin. Bulletin of Canadian Petroleum Geology 39, 18-42.

Price, F.T. \& Shieh, Y.N., 1979: Distribution and isotopic composition of sulfur in coals from the Illinois Basin. Economic Geology 74, 1445-1461. https://doi.org/10.2113/gsecongeo.74.6.1445.

Prothero, D.R. \& Schwab, F., 1996: Sedimentary geology: an introduction to sedimentary rocks and stratigraphy. W.H. Freeman and Company, 575 pp.

Reading, H.G. \& Collinson, J.D., 1996: Clastic coasts. In Reading, H.G. (ed.): Sedimentary Environments: Processes, Facies and Stratigraphy 3rd edition. Blackwell Science, pp. 154-231.

Reineck, H.E. \& Singh, I.B., 1972: Genesis of laminated sand and graded rhythmites in storm-sand layers of shelf mud. Sedimentology 18, 123-128. https://doi.org/10.1111/j.1365-3091.1972.tb00007.x.

Reineck, H.E. \& Wunderli, F., 1968: Classification and origin of flaser and lenticular bedding. Sedimentology 11, 99-104. https://doi.org/10.1111/j.1365-3091.1968.tb00843.x.

Reinson, G.E., 1992: Transgressive barrier island and estuarine systems In Walker, R.G. \& James, N.P. (eds.): Facies Models: response to sea level change. Geological Association of Canada, St Johns, pp. 179-194.

Retallack, G.J., 2001: Soils of the past: an introduction to paleopedology. Blackwells, 404 pp. https://doi.org/10.1002/9780470698716.

Schlegel, A., Lisker, F., Dörr, N., Jochmann, M., Schubert, K. \& Spiegel, C., 2013: Petrography and geochemistry of siliciclastic rocks from the Central Tertiary Basin of Svalbard -implications for provenance, 
tectonic setting and climate. Zeitschrift der Deutschen Gesellschaft für Geowissenschaften 164, 173-186. https://doi.org/10.1127/1860-1804/2013/0012.

Siggerud, E.I.H., \& Steel, R.J., 1999: Architecture and trace-fossil characteristics of a 10,000-20,000 year, fluvial-to-marine sequence, SE Ebro basin, Spain. Journal of Sedimentary Research 69, 365-383. https://doi.org/10.2110/jsr.69.365.

Silva, M.B., Kalkreuth, W. \& Holz, M., 2008: Coal petrology of coal seams from the Leao-Butia Coalfield, Lower Permian of the Parana Basin, Brazil - Implications for coal facies interpretations. International Journal of Coal Geology 73, 331-358. https://doi.org/10.1016/j.coal.2007.08.002.

Staub, J.R., 1991: Comparisons of central Appalachian Carboniferous coal beds by benches and a raised Holocene peat deposit. International Journal of Coal Geology 18, 45-69. https://doi.org/10.1016/0166-5162(91)90043-I.

Staub, J.R., 2002: Marine flooding events and coal bed sequence architecture in southern West Virginia. International Journal of Coal Geology 49, 123-145. https://doi.org/10.1016/S0166-5162(01)00074-X.

Steel, R. \& Dalland, A., 1978: Undersøkelser av den kullførende del av Firkanten Formasjonen (Tertiær) i $\emptyset$ stlige del av Nordenskiøld land Svalbard. Geologisk Institutt Universitetet i Bergen, pp. 62.

Steel, R. \& Worsley, D., 1984: Svalbard's post-Caledonian strata - an atlas of sedimentological patterns and palaeogeographic evolution. In Spencer, A.M. (ed.): Petroleum Geology of the North European margin. Graham and Trotman, pp. 109-135. https://doi.org/10.1007/978-94-009-5626-1_9.

Steel, R., Dalland, A., Kalgraff, K.L. \& Larsen, V., 1981: The central Tertiary basin of Spitsbergen sedimentary development in a sheared margin basin. In Kerr, J.W., \& Fergusson, A.J. (eds.): Geology of the North Atlantic Borderlands. Canadian Society of Petroleum Geologists, Memoir 7, pp. 647-664.

Steel, R., Gjelberg, J., Helland-Hansen, W., Kleinspehn, K., Nøttvedt, A. \& Rye-Larsen, M., 1985: The Tertiary strike-slip basin and orogenic belt of Spitsbergen. SEPM Special Publication No. 39, pp. 339-359. https://doi.org/10.2110/pec.85.37.0339.

Van Wagoner, J.C., Mitchum, R.M.J., Campion, K.M. \& Rahmanian, V.D., 1990: Siliciclastic sequence stratigraphy in well logs, cores, and outcrops: Concepts for high-resolution correlation of time and facies. Methods in Exploration Series, No. 7. American Association of Petroleum Geologists 55, pp. 35. https://doi.org/10.1306/Mth7510.

Wadsworth, J., Boyd, R., Diessel, C., Leckie, D. \& Zaitlin, B.A., 2002: Stratigraphic style of coal and non-marine strata in a tectonically influenced intermediate accommodation setting: the Mannville Group of the Western Canadian Sedimentary Basin, south-central Alberta. Bulletin of Canadian Petroleum Geology 50, 507-541. https://doi.org/10.2113/50.4.507.

Wadsworth, J., Boyd, R., Diessel, C. \& Leckie, D., 2003: Stratigraphic style of coal and non-marine strata in a high accommodation setting: Fahler and Gates Formation (Lower Cretaceous), western Canada. Bulletin of Canadian Petroleum Geology, v. 51, 275-303. https://doi.org/10.2113/51.3.275.

Walker, R.G. \& Plint, A.G., 1992: Wave- and storm-dominated shallow marine systems. In Walker, R.G. \& James, N.P. (eds.) Facies Models: response to sea level change. Geological Association of Canada, St Johns, pp. 219-238. 
Ward, C.R., 1984: Coal geology and coal technology. Blackwell Scientific Publications, 345 pp.

Watts, A.B., 1992: The effective elastic thickness of the lithosphere and the evolution of foreland basins. Basin Research 4, 169-178. https://doi.org/10.1111/j.1365-2117.1992.tb00043.x.

Wilhelmsson, J.C., 1999: Depositional Environment and Sequence Stratigraphy of the Coal-bearing Todalen Member, Firkanten Formation (Paleocene) at Adventdalen, Svalbard. Cand. Scient. University of Oslo, 89 pp.

Winsnes, T.S., 1988: Bedrock Map of Svalbard and Jan Mayen, 1:1000 000 Norsk Polarinstitutt Temakart, Norwegian Polar Institute.

Winston, R.B., 1994: Models of the geomorphology, hydrology, and development of domed peat bodies. Geological Society of America Bulletin 106, 1594-1604.

https://doi.org/10.1130/0016-7606(1994)106<1594:MOTGHA>2.3.CO;2.

Worsley, D., Aga, O.J., Dalland, A., Elverhøi, A. \& Thon, A., 1986: The Geological History of Svalbard, Evolution of an Arctic Archipelago. Statoil, Asker Trykkeri, Stavanger, 121 pp. 